\title{
Developing a Service Quality Framework for a Special Type of Course
}

\author{
Vivien Surman ${ }^{1 *}$, Zsuzsanna Eszter Tóth² \\ 1 Department of Management and Business Economics, Faculty of Economic and Social Sciences, Budapest University of \\ Technology and Economics, H-1117 Budapest, Magyar Tudósok krt., 2, Hungary \\ 2 Department of Management and Business Law, Institute of Business Economics, Eötvös Loránd University, \\ H-1053 Budapest, Egyetem tér, 1-3, Hungary \\ * Corresponding author, e-mail: surman@mvt.bme.hu
}

Received: 08 March 2018, Accepted: 16 April 2018, Published online: 28 January 2019

\begin{abstract}
This paper addresses the issue of service quality measurement and evaluation in higher education and stresses the need to develop sound measures for special types of courses. During these courses students carry out project works under special circumstances and with special characteristics compared to "ordinary" courses where traditional course evaluation methods have been applied for a long time. The primary aim of the paper is to support the need to develop valid, reliable and replicable measures of service quality in case of these courses. Therefore, a questionnaire was designed for these courses to collect students' perceptions. The results are reported by using an importance-performance analysis supplemented by the draw of statistical conclusions. The presented methodology allows the identification of importance-performance gaps and supports the assessment of quality improvement programs.
\end{abstract}

Keywords

higher education, service quality, student satisfaction, course evaluation, importance-performance analysis

\section{Introduction}

In many countries, higher education (HE) has transformed to a mass market service in which growing number of students are served by an increasing number and diversity of service providers. Therefore, a renewed focus on higher education has been felt recently. Higher education institutions (HEIs) seek more effective systems to fulfil the rising need for transparency and accountability and to enhance the overall satisfaction with the performance of HE systems (Kwan, 1999).

The expansion of HE and the increasing costs together with demographic shifts in the population stresses institutions to have another thought about the role of quality (Kotler and Fox, 1995). Among the numerous challenges HEIs have to face, universities have started to realize that their long-term success depends on how good their services are. There is the need to take on the expectations of students as HEIs are now competing for them both on national and international level. As a result, paying more attention to quality issues has become a common trend in the development of HE services. Accordingly, quality is now viewed as an opportunity to gain competitive advantage (Aly and Akpovi, 2001; Borahan and Ziarati, 2002).

$\mathrm{HE}$ has all the characteristics a service includes such as intangibility, heterogeneity, perishability and inseparability (Arokiasamy, 2012; Cuthbert, 1996a; 1996b; Ong and Nankervis, 2012). Intangibility means that educational services are difficult for customers to understand (Zeithaml and Bitner, 2002), so HEIs need to provide tangible cues to service quality and reduce its complexity anywhere it is possible (Clewes, 2003). Due to heterogeneity it is difficult to standardize educational services, so there has to be an opportunity for students to give feedback about their experiences, which should be part of the evaluation system related to courses (Clewes, 2003). "Production" and "consumption" of HE services are inseparable as they take place at the same time. In that sense it is a matter for students who their lecturers are (Clewes, 2003). Perishability means that higher education services cannot be stored.

The definition and measurement of service quality (SQ) has been the subject of much debate over the last two 
decades (Dale, 2003) with special attention to the development of valid, reliable and replicable measures of service quality (Dale, 2003; Oldfield and Baron, 2000; Rowley, 1997). Owlia and Aspinwall (1996) were the first to give an explanation of service quality dimensions in higher education. Currently, there is still no general agreement on the measurement of SQ, or on the dimensions and their importance in higher educational context. Perceived service quality is undoubtedly of paramount strategic importance (Bemowski, 1991; Peters, 1992) in order to recruit and retain students and to enhance student satisfaction. Recently, the studies on the development and application of a HE specific SQ model are increasing. Most of the models use SERVQUAL as a basis, others utilize the methodology of SERVPERF based on the critics of the former one (see e.g. Abdullah, 2006a; 2006b; Kincsesné et al., 2015; Lupo, 2013; Teeroovengadum et al., 2016).

As an attempt to improve the quality of their services, most European HEIs have already implemented some forms of student satisfaction measurements by paying more attention to meeting the expectations and needs of their students (Çelik et al., 2018; DeShields et al., 2005; Mai, 2005; Marzo-Navarro et al., 2005; Palacio et al., 2002). Student surveys may serve several management purposes. Firstly, they are comprehensive tools for planning and implementing continuous improvement activities. Secondly, as a managerial tool they stress HEIs to adapt to the changing circumstances of the HE market (Wiers-Jenssen et al., 2002).

Many HE studies on service quality aspects have concentrated on effective course delivery mechanisms and the quality of teaching and courses (Athiyaman, 1997; Bourner, 1998; Cheng and Tam, 1997). There is a wide range of instruments in use to collect students' feedbacks (Brennan and Williams, 2004). If we wish to focus on course quality, formal measurements tend to be conducted through course evaluations usually completed by students at the end of a term. It is considered as a feedback mechanism which pinpoints the strength of courses and identifies areas of improvement. It should help to reduce the gap between what the lecturers perceive and what the students perceive as the quality of teaching (Venkatraman, 2007).

In this paper the development and the pilot application of a SERVQUAL-based course evaluation questionnaire is introduced and the first results are demonstrated. The Likert scale based questionnaire was developed for specific purposes, namely, for the measurement and evaluation of service quality aspects in case of project work type courses which are not part of the traditional student evaluation of education (SEE) framework. The main motivation of developing and delivering such a questionnaire was the fact that these project works express the "path" towards a successful thesis work, and therefore, may play a significant role in the total student HE experience.

The paper is structured as follows. Section 2 gives an overview of the relevant service quality literature in HE. Section 3 describes the main characteristics of project work type courses compared to traditional courses. Section 4 outlines the applied methodology, while Section 5 interprets the first results of that kind of survey application. Section 6 summarizes the research implications and managerial conclusions. Finally, research limitations and possible future research directions are discussed.

\section{Literature review}

\subsection{Characteristics of service quality in higher education - the role of students}

Recently, increasing attention has been paid to the improvement of educational service quality (Lupo, 2013), however, even to find a general definition for quality in higher education is still a challenging task (Khodayari and Khodayari, 2011; MaCukow, 2000).

The definition of quality not only depends on in which specific service sector it is evaluated, but which particular stakeholder group is in focus and what kind of quality dimensions could be distinguished. Service quality in HE is a complex phenomenon (Qureshi et al., 2012) due to the great number of stakeholders including the academic and non-academic staff, funding bodies, parents, companies, government and students (Tam, 2001; Trivellas and Dargenidou, 2009; Rowley, 1997) and to their multidimensional role in educational processes.

Most studies consider students as primary customers (e.g. Bala et al., 2011; Bhuian, 2016; Gremler and McCollough, 2002; Hill, 1995; Hung et al., 2003; Iş1k et al., 2011; Malik and Naeem, 2011; Sander et al., 2000; Chen, 2011; Yeo, 2008). According to Marzo-Navarro et al. (2005) students are the priority customers since they are directly provided with higher educational services. Nevertheless, students not only act as customers, but they are clients, co-producers and "products" at the same time in the educational processes (Green, 1994; Guolla, 1999; Hill, 1995; Khodayari and Khodayari, 2011; Senthilkumar and Arulraj, 2011). What is more, students form a group of internal customers as well (Mazur, 1996; Reavill, 1998). Sirvanci (1996) defined the roles of students as 
Table 1 Service quality measuring models

\begin{tabular}{|c|c|c|c|c|c|c|}
\hline SERVQUAL & SERVPERF & HEdPERF & EDUQUAL & COURSEQUAL & HESQUAL & TEDPERF \\
\hline $\begin{array}{c}\text { Parasuraman et } \\
\text { al., } 1988\end{array}$ & $\begin{array}{l}\text { Cronin and } \\
\text { Taylor, } 1992\end{array}$ & $\begin{array}{l}\text { Abdullah, 2006a; } \\
\text { 2006b }\end{array}$ & $\begin{array}{c}\text { Mahapatra and } \\
\text { Khan, } 2007\end{array}$ & $\begin{array}{l}\text { Kincsesné et al., } \\
2015\end{array}$ & $\begin{array}{c}\text { Teeroovengadum et } \\
\text { al., } 2016\end{array}$ & $\begin{array}{c}\text { Rodríguez-González } \\
\text { and Segarra, } 2016\end{array}$ \\
\hline $22 * 2$ & 22 & 41 & 28 & 24 & 48 & 18 \\
\hline $\begin{array}{l}\text { tangibles, } \\
\text { reliability, } \\
\text { responsiveness, } \\
\text { assurance, } \\
\text { empathy } \\
\text { (RATER) }\end{array}$ & $\begin{array}{l}\text { tangibles, } \\
\text { reliability, } \\
\text { responsiveness, } \\
\text { assurance, } \\
\text { empathy }\end{array}$ & $\begin{array}{l}\text { non-academic } \\
\text { aspects, } \\
\text { academic aspects, } \\
\text { reputation, } \\
\text { access, } \\
\text { program issues, } \\
\text { understanding }\end{array}$ & $\begin{array}{c}\text { learning } \\
\text { outcomes, } \\
\text { responsiveness, } \\
\text { physical facilities, } \\
\text { personality } \\
\text { development, } \\
\text { academics }\end{array}$ & $\begin{array}{l}\text { cooperation, } \\
\text { reliability of } \\
\text { teaching method, } \\
\text { assurance and } \\
\text { punctuality, } \\
\text { empathy, } \\
\text { tangibles }\end{array}$ & $\begin{array}{c}\text { administrative quality, } \\
\text { physical environment } \\
\text { quality, core } \\
\text { educational quality, } \\
\text { support facilities } \\
\text { quality, transformative } \\
\text { quality }\end{array}$ & $\begin{array}{c}\text { non-academic } \\
\text { aspects, academic } \\
\text { aspects, reputation, } \\
\text { (access), } \\
\text { program issues, } \\
\text { (understanding) }\end{array}$ \\
\hline
\end{tabular}

product-in-process, internal customers for facilities, laborers in the learning process and internal customers for the delivery of course materials.

As students are both co-creators and co-producers in the educational service, their involvement is a must to measure, analyze and assess the service experience. That is why the delight of students is crucial in increasing the prestige of the institution when adapting to the rising international competition, improving the quality of higher education services and raising academic standards in accordance with international trends (O'Neill and Palmer, 2004). In order to ensure the quality of higher education, every HEI should have a system in place to monitor and measure the teaching performance by putting the students, their experience and perspective into the forefront (Andersson et al., 2009; Bedzsula and Topár, 2014).

\subsection{Service quality measurement in higher education}

It is a challenging and complex task to establish an appropriate model to measure the level of higher education service quality (Chong and Ahmed, 2012; Hadikoemoro, 2001; Ramaiyah et al., 2007). Universities employ a mix of qualitative (e.g. interviews, focus groups) and quantitative (questionnaires) methods to collect students' feedbacks (O'Neill and Palmer, 2004).

A remarkable part of relevant research concludes that student surveys play a dominant role in the measurement and evaluation of HE service quality (Williams, 2002). According to Clewes (2003), there are three major approaches:

1. methods adapting the SERVQUAL instrument (e.g. Cuthbert, 1996a; 1996b; Donaldson and Runciman, 1995; Oldfield and Baron, 2000; O'Neill and Palmer, 2001; Owlia and Aspinwall, 1996; Rigotti and Pitt, 1992) (see Table 1 as a summary of the most popular methods);
2. methods applied for the assessment of teaching and learning quality (Entwistle and Tait, 1990; Marsh and Roche, 1993; Ramsden, 1991);

3. methods assessing total student experience (Aldridge and Rowley, 1998; Geall, 2000; Harvey et al., 1992; Hill, 1995; Roberts and Higgins, 1992; Watson et al., 2002; Wiers-Jenssen et al., 2002).

Due to the growing debate on the multifaceted definition of quality in HE and students being the prior customers, service quality measurements and evaluations are mainly based on student perceptions (Alves and Raposo, 2009; Mai, 2005) by highly considering student satisfaction results (Arokiasamy, 2012; Paswan and Ganesh, 2009). Lewis and Booms (1983, p. 100) concludes service quality as a "measure of how well the service level delivered matches the customer's expectations". Others claim it is about service superiority (e.g. Abdullah, 2006a; 2006b). Parasuraman et al. (1988) suggest a comparison of performance perceptions with expectations on a 7-point Likert scale from "strongly agree" (7) to "strongly disagree" (1). The SERVQUAL model originating from the gap theory (Parasuraman et al., 1985) measures service quality originally with 97 statements in 10 dimensions which were later reduced to 22 statements with 5 dimensions in the final model (Parasuraman et al., 1988):

- Tangibles: physical facilities, equipment, appearance of personnel;

- Reliability: the ability to perform the desired service dependably, accurately, and consistently;

- Responsiveness: the willingness to provide prompt service and help customers;

- Assurance: employees' knowledge, courtesy, and ability to convey trust and confidence; and

- Empathy: the provision of caring, individualized attention to customers. 
The SERVQUAL model and its methodology have earned a great popularity which is utilized extensively in the HE sector as well (Kincsesné et al., 2015; Lupo, 2013; Teeroovengadum et al., 2016). Apart from the wide range of applications in different sectors, the model has also received plenty of criticism among which many researchers argued for measuring service quality taking only perceived performance into consideration (Abdullah, 2006a; 2006b; Cronin and Taylor, 1992; Trivellas and Dargenidou, 2009). According to Teas (1993), these perceptions should be analyzed in connection with the ideal standards and not with the expectations. The author also highlights that they are similar, but not the same. The I (ideal) value suggests that perceived quality $(\mathrm{P})$ increases as $\mathrm{P}$ increasingly exceeds expectations, so this model concludes that perceived quality might decrease as perceptions increasingly exceed the ideal point (Teas, 1993).

Another way to investigate quality could be the study of customer perceptions solely. According to Cronin and Taylor (1992), service quality is the foundation of student satisfaction and loyalty. They propose the unweighted perception components of SERVQUAL which results in the SERVPERF model. Their empirical results prove a better predictive power, but on the other hand, SERVQUAL provides more information (Boulding et al., 1993; Kincsesné et al., 2015; Quester et al., 1995; Voss et al., 2007).

Abdullah (2006a; 2006b) developed a SERVPERFbased service quality measuring scale (HEdPERF) specifically to the HE sector by distinguishing six dimensions of service quality such as non-academic aspects, academic aspects, reputation, access, program issues, and understanding. HEdPERF includes 41 statements to measure all the characteristics of the total service environment as experienced by the students from a holistic perspective (Brochado, 2009). From the 41 statements, 13 originated from SERVPERF and 28 were generated based on an extensive literature review.

Mahapatra and Khan (2007) developed the EDUQUAL model to technical institutions, where the differences between expectations and perceptions were analyzed similarly to SERVQUAL with the following dimensions: learning outcomes, responsiveness, physical facilities, personality development, academics.

In the 2010s research on service quality is still intensive. The observation and assessment of service quality in each sector are becoming an increasing trend (Prasad and Jha, 2013) and as a result, many new models have started to evolve. A typical form of assessing service quality in this sector is focusing on the quality of courses. Kincsesné et al. (2015) established a SERVQUAL-based COURSEQUAL model including 24 statements in 5 dimensions evaluating each on a 5-point Likert scale. Four items were used to measure student satisfaction:

- perceived importance of the course content for the career of the student,

- the course worth the need to pay tuition fee for the education,

- the teacher's education method increased the student's interest towards the topic,

- overall satisfaction with the course.

Teeroovengadum et al. (2016) introduced the model of HESQUAL applying 5 dimensions (administrative quality, physical environment quality, core educational quality, support facilities quality, transformative quality) with 9 sub-dimensions to measure the level of service quality in HEIs. It is a performance-only measurement methodology applying a 5-point Likert scale with 48 items.

Rodríguez-González and Segarra (2016) proposed the TEdPERF model for tertiary education on the base of HEdPERF including 18 statements evaluated on a 7-point Likert scale.

Besides SERVQUAL, another major approach to measure the level of service quality is the importance-performance technique which is "an absolute performance measure of customer perceptions" (Wright and O'Neill, 2002). This tool helps to identify the failures of the service and address continuous quality improvement efforts (Ford et al., 1999; Martilla and James, 1977; McLeay et al., 2017; Tóth et al., 2013). The importance-performance analysis (IPA) is getting popular, because apart from its simplicity and easiness to use, it has a great diagnostic value (e.g. O'Neill and Palmer, 2004). Performance includes the experiences of customers which can be changed and improved without affecting the importance. Importance shows the relative value of the various quality attributes from the customers' point of view. These express what is important for the customers. The item having lower importance plays a smaller role in the overall satisfaction, while items with higher importance embody crucial factors. The result of IPA is typically drawn to the importance-performance map. The I-P map involves four main parts in the form of quadrants. The attributes in the right upper quadrant have both high importance and performance, while in the left lower quadrant these are the opposite with low performance and low importance levels. In the left upper 
quadrant, the important but low-performing attributes are situated, while in the right lower quadrant are the unimportant and high-performing ones (Fig. 2). When applying an importance-performance map, the positioning of the vertical and horizontal axes is a matter of judgement (O’Neill and Palmer, 2004).

\subsection{Course evaluation as a mean of student perception measurement}

Numerous studies have been conducted to measure student satisfaction at university level all over Europe (DeShields et al., 2005; Mai, 2005; Marzo-Navarro et al., 2005; Palacio et al., 2002; Wiers-Jenssen et al., 2002) by implementing some form of student evaluation of teaching (Wiers-Jenssen et al., 2002). There is a wide range of instruments in use to collect students' feedbacks (e.g. Brennan and Williams, 2004; Brochado, 2009; Gruber et al., 2010; Richardson, 2005) in order to assess the quality of teaching and learning from the primary customers' aspect. Student satisfaction surveys are commonly used in HEIs as feedback mechanisms to determine the delivery of education. They are considered to be a comprehensive tool for planning and implementing continuous improvements, and therefore, stress institutions to keep pace with the ever changing requirements of the market (Gruber et al., 2010; Wiers-Jenssen et al., 2002).

If we wish to focus on course quality, formal measurements tend to be conducted through course evaluations completed by students at the end of a term. Student feedbacks provide auditable evidence that students have had the opportunity to comment on their courses and that such information is used to bring about improvements and encourage student reflection on their learning (Grebennikov and Shah, 2013, Tóth and Jónás, 2014; Rowley, 2003).

The measurement of student satisfaction focusing on their experiences in HE is now commonplace in Hungary as well to raise the level of expected and delivered service quality related both to teaching and learning. HEIs tend to implement methods for measuring and evaluating student experience. In most cases these measurements are realized through in-house standardized feedback questionnaires focusing on different aspects of students' experience.

The formal measurement of course quality called Student Evaluation of Education (SEE) has been executed at the Budapest University of Technology and Economics at the end of each and every semester since 1999. SEE is based on a student questionnaire focusing on the quality level of lecturers' classroom performance. Since its first implementation, the SEE framework has been revised and improved many times. Students are invited to fill in the electronic survey at the end of each semester related to all courses they have completed and earned a final grade. The questionnaire is anonymous. Moreover, it is optional for students to take part in the evaluation process, and any questions of the questionnaire can be skipped.

The SEE survey measures different dimensions of teaching quality taking a semester-long performance into consideration. The questionnaire is made up of two parts. The first part includes questions depending on the type of the course (namely, lecture, seminar or lab), and the second part covers general questions about a certain course. Beyond the average values given to each question related to both lecturers and courses, new indices have been developed such as the Course Quality Index (CQI) and the Teaching Quality Index (TQI). It is a great reputation for a lecturer to be on the top 100 list of best professors which is based on the ranking of TQIs (Bedzsula and Kövesi, 2016).

\section{Project work courses and their special characteristics} Fulfilling different levels of project works is a must for hundreds of BA and MA students at the Faculty of Economic and Social Sciences. In case of these project work courses, students do not have the opportunity to evaluate these courses and reflect their judgement formally by applying a standardized questionnaire in the framework of regular SEE.

Project works are complex courses, the fulfilment of the detailed tasks is based on the execution of practice-oriented problems utilizing the students' professional knowledge in mathematics, business economics, finance, management and marketing. Project works are accomplished either individually or in small teams. The primary aim of these courses is to solve real-life problems, carry out complex solutions utilizing the knowledge of previous studies by taking part in relevant organizational projects. When enrolling for project work courses, students rank their preferences according to their interests in the topics offered by the involved departments of the faculty. Students are allocated to the different topics by taking their rankings and average study results into consideration in order to ensure the balanced load of the lecturers and the departments involved as consultants in the consultation process. When listing the tasks of a project work in a given semester, lecturers are quite flexible to consider the special interests of students in a given topic. During the semester students are to accomplish the different tasks set for that period by consulting regularly about the progress with assigned lecturers 
as consultants and presenting their milestones in the form of oral reports during or at the end of the semester. The output of each semester is a written paper which is evaluated according to specific aspects about which students are informed at the beginning of the semester.

In case of BA or BSc programs there are two or three levels of these courses depending on the type of the program, while in case of MA and MSc programs one semester of project works are to be accomplished before writing the final thesis (Table 2).

The goals of the different levels of project works vary as these courses are meant to embody milestones towards a successful thesis work. In other words, project works are successive steps of the process which coach students how to write a thesis. Therefore, the purpose of the course titled Project work I. is to get acquainted with the theoretical background of a specific field when students have to deepen their knowledge in a given topic. At the same time, it is also possible for the students to start taking part in an organizational project in those cases when they already have organizational partnerships.

In case of the course titled Project work II., students usually solve a specific organizational issue related to the topic deepened during Project work I. If it is possible, students analyze and investigate the given problem by assisting in the everyday life of a chosen organization.

The aim of the course named Project work III. (in case of the programs where it is an obligatory course for students, see Table 2) is to go further compared to the results of Project work II. both in implementation and in theory, if needed, in order to offer a solution of the examined organizational problem in a more sophisticated manner.
The thesis work generally involves the processing of a more comprehensive problem, therefore, requires the utilization of various tools and the complex knowledge base of previous professional courses. In the preceding project works the requirement is the step by step solution of the problem. During both fulfilling the project works and the thesis, students have to demonstrate that they are able to apply the specific methodologies, related tools and methods in a professional way when solving a real-life problem. To put it simply, they are able to utilize their professional knowledge and the available information of the relevant literature to analyze and investigate a specific organizational problem. Based on the results of the analyst phase, they are able to propose a professionally relevant solution to the given problem by considering all possible opportunities and conditions.

During these semesters students work under the guidance of a consultant employed at the department to which the topic of the project work is scientifically related. The consultant's role is to offer a partnership by assisting the student through the flow of project works and thesis with suggestions and recommendations by regularly discussing the different steps.

After the students completed and uploaded the written results of their project work, they prepare an oral presentation where their semester-long work processes and results are presented. Additionally, it is of high importance to improve their presentation skills as well.

The Department of Management and Business Economics belonging to the Faculty of Economic and Social Sciences has always tried to find ways to collect student feedbacks related to project work courses. This department plays a significant leading role in the aforementioned programs, namely, in Engineering Management BSc,

Table 2 Characteristics of project work courses in different programs

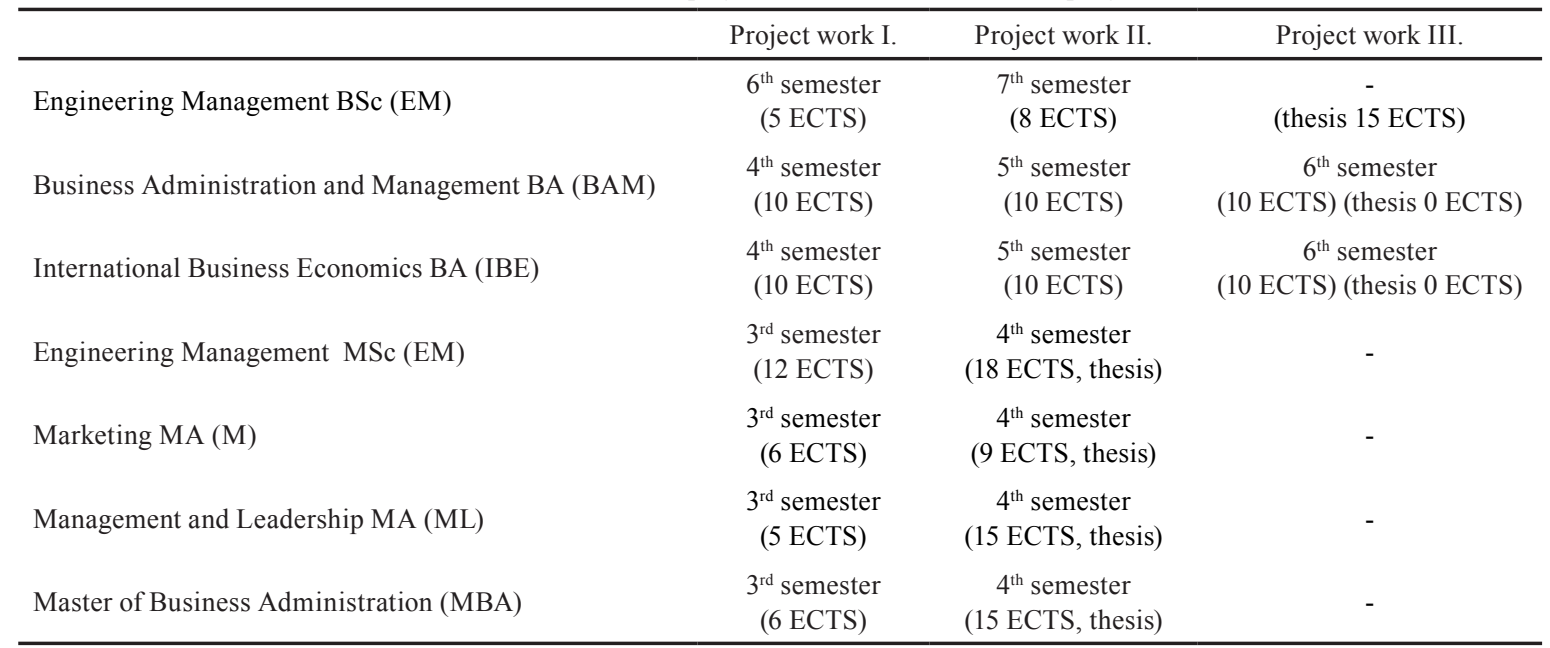


Engineering Management MSc, Business Administration and Management BA, International Business Economics BA, Marketing MA, Management and Leadership MA, Master of Business Administration (MBA). Students of these programs must fulfill project works on different levels, semesters, and for different ECTSs (European Credit Transfer System) (Table 2). Table 3 demonstrates the number of students consulted at the Department in the previous 7 semesters in order to illustrate the sequence of student numbers according to the different types of project work courses.

\subsection{Initiatives for developing a framework of service quality in case of project work courses}

Student evaluations of project works are not part of the university's official course evaluation system (SEE) due to their highly special characteristics. In case of these courses there are no contact lectures. Students are usually invited to take part in an introductory session at the beginning of the semester where they are informed about both the requirements and the work and administration processes. Henceforth, they work together with the appointed lecturer.

There are many differences compared to traditional courses. Students work on the accomplishment of different tasks with their consultants. They deal with various topics and real-life organizational problems with different lecturers from different departments. Students are provided individual attention during the semesters as they work together in a close partnership. As project works play a significant role in the final "product" of the student, namely, the thesis, it is of high importance how they experience the service provided by their consultants during these semesters.

According to the previously mentioned, the consultancy of project works is a special kind of educational service during their studies. Therefore, the quality of the partnership

\begin{tabular}{|c|c|c|c|c|}
\hline & & Project work I. & Project work II. & Project work III. \\
\hline \multirow{4}{*}{ 2017/2018/I. } & EM BSc & 31 & 60 & - \\
\hline & BAM BA & - & 74 & 15 \\
\hline & IBE BA & 1 & 69 & 10 \\
\hline & Mark. MA & 59 & - & - \\
\hline \multirow{4}{*}{ 2016/2017/II. } & EM BSc & 79 & 17 & - \\
\hline & BAM BA & 76 & 7 & 66 \\
\hline & IBE BA & 75 & 8 & 47 \\
\hline & Mark. MA & 9 & - & - \\
\hline \multirow{4}{*}{ 2016/2017/I. } & EM BSc & 12 & 63 & - \\
\hline & BAM BA & - & 70 & 5 \\
\hline & IBE BA & - & 48 & 10 \\
\hline & Mark. MA & 45 & - & - \\
\hline \multirow{4}{*}{ 2015/2016/II. } & EM BSc & 68 & 9 & - \\
\hline & BAM BA & 73 & 5 & 51 \\
\hline & IBE BA & 54 & 7 & 37 \\
\hline & Mark. MA & - & - & - \\
\hline \multirow{4}{*}{ 2015/2016/I. } & EM BSc & 3 & 61 & - \\
\hline & BAM BA & - & 49 & 11 \\
\hline & IBE BA & - & 42 & 12 \\
\hline & Mark. MA & 46 & - & - \\
\hline \multirow{4}{*}{ 2014/2015/II. } & EM BSc & 63 & 21 & - \\
\hline & BAM BA & $58 / 57$ & 6 & 40 \\
\hline & IBE BA & $44 / 43$ & 5 & 36 \\
\hline & Mark. MA & - & - & - \\
\hline \multirow{4}{*}{ 2014/2015/I. } & EM BSc & $9 / 7$ & 41 & - \\
\hline & BAM BA & - & 38 & 17 \\
\hline & IBE BA & - & 44 & 9 \\
\hline & Mark. MA & - & - & - \\
\hline
\end{tabular}


between the student and lecturer and the attention paid by the consultant to the students may determine significantly the students' total experience in higher education. The consultant's performance also has a significant influence on the student's final project work. If we consider that consultants have naturally different personality, professional and scientific interest and knowledge level, it is clear that they might not focus on the same factors. Moreover, these courses are significant parts of the curriculum in a given program, and a thesis for students can serve as a basis of choosing a career and finding a job (Bérces, 2015; Finna and Erdei, 2015; Perger and Takács, 2016). During project works, students can master the necessary professional knowledge and those inevitable soft skills which are needed to be successful in the labor market. It is clear that in case of project works most of the existing and widely used course evaluation methods are not working due to their special characteristics.

The Department of Management and Business Economics has previously attempted to collect student feedbacks related to the consultancy processes and consultants of project works. The former questionnaires applied for this purpose were different in their lengths, forms and content. They were mostly paper based, students filled it out usually after their end-of-semester oral presentations. Results were fed back to the lecturers, but they were not enforced to react to their results. Some part of the results was utilized in the internal processes on departmental level which means that related administrative and other supporting processes were adjusted. In some aspects the former results also served as a basis for setting standards in order to continuously improve the project work related processes. At the same time, only limited quantitative analysis was conducted from the results, as that was not the primary aim. These attempts may be considered as finding the right way to collect student feedbacks, however, that was not clear what the primary purpose was, for what the results were going to be utilized, what the consequences of different performance levels were and how the results were meant to fed back to the related processes.

In the followings the consultancy service quality of project works of four programs are going to be evaluated, namely, of Engineering Management BSc, Business Administration and Management BA, International Business Economics BA, and Marketing MA. The reason for focusing on these programs is the fact that the Department has the professional responsibility over these programs and on the other hand, the students fulfilling their project works at the Department study on one of these programs. (Table 3)

\section{Survey development}

Based on the aforementioned, the primary aim was to develop a SERVQUAL-based methodology to collect and analyze student feedbacks in case of project work courses. The following questions have arisen: Is there any difference between lecturers? Is there any difference between the subgroups of the department embodying different professional knowledge and project work topics? Is there a significant difference between the requirements of students studying in different programs or at different levels? Before answering these research questions, reliability measures related to the applicability are to be identified and analyzed.

As it was previously highlighted in the literature review, the research is extensive on the application of service quality models in HE based on different levels of student feedbacks. A number of HE studies widely apply the SERVQUAL methodology and its dimensions (see e.g. Cuthbert, 1996a; 1996b; Pariseau and McDaniel, 1997; Soutar and McNeil, 1996; Wong et al., 2012). The quality of project work type courses was surveyed by developing a more detailed questionnaire compared to the one in use at BME (official abbreviation of the university) for course evaluations with the aim of getting a deeper knowledge of students' judgement by extending and customizing the relevant aspects. The statements of our survey were primarily based on questionnaires proposed by Oldfield and Baron (2000), Yousapronpaiboon (2014) and Kincsesné et al. (2015), the latter two of which are based on SERVQUAL. Furthermore, four students who take part closely in the educational and research processes of the department were also involved in finalizing the statements in order to make it more understandable for students.

Our survey applied for the measurement and evaluation of the service quality of project work consultation consists of 26 statements. Additional 2 questions complement the statements, the first expressing an overall evaluation and the other one standing for narrative comments. The 26 statements of the survey questionnaire are listed in Table 4. In this paper the importance of the statements and the consultant's semester-long performance level is analyzed with importance-performance analysis. Therefore, students were asked to express their opinion in two dimensions, namely, scoring the importance and the performance related to each statement using a Likert scale from 1 through 7, where score 1 stands for the lowest, and score 7 for the highest value in both dimensions. The performance dimension of a statement reflects how much the students are satisfied with the performance in 
Table 4 Survey questionnaire

\begin{tabular}{|c|c|c|c|c|c|c|c|c|c|c|c|c|c|c|}
\hline 1 & 2 & 3 & 4 & 5 & 6 & 7 & $\begin{array}{l}\text { S1 - The guidelines related to the content requirements of the project work are clear } \\
\text { and can be well used. }\end{array}$ & 1 & 2 & 3 & 4 & 5 & 6 & 7 \\
\hline 1 & 2 & 3 & 4 & 5 & 6 & 7 & $\begin{array}{l}\text { S2 - The guidelines related to the formatting requirements are clear and can be well } \\
\text { used. }\end{array}$ & 1 & 2 & 3 & 4 & 5 & 6 & 7 \\
\hline 1 & 2 & 3 & 4 & 5 & 6 & 7 & $\begin{array}{l}\text { S3 - Consultant feedbacks on the different phases of the project work are provided } \\
\text { both in an interpretable way and form. }\end{array}$ & 1 & 2 & 3 & 4 & 5 & 6 & 7 \\
\hline 1 & 2 & 3 & 4 & 5 & 6 & 7 & S4 - The consultant offers appropriate, suitable consultation opportunities. & 1 & 2 & 3 & 4 & 5 & 6 & 7 \\
\hline 1 & 2 & 3 & 4 & 5 & 6 & 7 & $\begin{array}{l}\text { S5 - The consultant uses up-to-date tools and methods during consultations and when } \\
\text { giving feedbacks. }\end{array}$ & 1 & 2 & 3 & 4 & 5 & 6 & 7 \\
\hline 1 & 2 & 3 & 4 & 5 & 6 & 7 & $\begin{array}{l}\text { S6 - Consultations take place in an undisturbed environment with appropriate } \\
\text { conditions. }\end{array}$ & 1 & 2 & 3 & 4 & 5 & 6 & 7 \\
\hline 1 & 2 & 3 & 4 & 5 & 6 & 7 & $\begin{array}{l}\text { S7 - The consultant keeps the jointly agreed deadlines which supports the continuous } \\
\text { progress of the project work. }\end{array}$ & 1 & 2 & 3 & 4 & 5 & 6 & 7 \\
\hline 1 & 2 & 3 & 4 & 5 & 6 & 7 & S8 - The consultant is ready to help with the problems arising from the student. & 1 & 2 & 3 & 4 & 5 & 6 & 7 \\
\hline 1 & 2 & 3 & 4 & 5 & 6 & 7 & $\begin{array}{l}\text { S9 - During the consultations the consultant shows his/her willingness to share his } \\
\text { knowledge in an appropriate and understandable way. }\end{array}$ & 1 & 2 & 3 & 4 & 5 & 6 & 7 \\
\hline 1 & 2 & 3 & 4 & 5 & 6 & 7 & $\begin{array}{c}\text { S10 - The consultant pays attention to the student's interest related to the topic of the } \\
\text { project work. }\end{array}$ & 1 & 2 & 3 & 4 & 5 & 6 & 7 \\
\hline 1 & 2 & 3 & 4 & 5 & 6 & 7 & S11 - The consultant is available at the agreed dates. & 1 & 2 & 3 & 4 & 5 & 6 & 7 \\
\hline 1 & 2 & 3 & 4 & 5 & 6 & 7 & $\begin{array}{l}\text { S12 - The consultant is willing to answer the emerging questions and requests during } \\
\text { consultation opportunities. }\end{array}$ & 1 & 2 & 3 & 4 & 5 & 6 & 7 \\
\hline 1 & 2 & 3 & 4 & 5 & 6 & 7 & $\begin{array}{c}\text { S13 - The number and the frequency of consultations during the semester are } \\
\text { sufficient. }\end{array}$ & 1 & 2 & 3 & 4 & 5 & 6 & 7 \\
\hline 1 & 2 & 3 & 4 & 5 & 6 & 7 & S14 - The consultant's response time to requests is appropriate. & 1 & 2 & 3 & 4 & 5 & 6 & 7 \\
\hline 1 & 2 & 3 & 4 & 5 & 6 & 7 & $\begin{array}{l}\text { S15 - The consultant's recommendations and expectations are consistent with the } \\
\text { guidelines related to the content of the project work. }\end{array}$ & 1 & 2 & 3 & 4 & 5 & 6 & 7 \\
\hline 1 & 2 & 3 & 4 & 5 & 6 & 7 & $\begin{array}{l}\text { S16 - The student are given enough help when doing research on the relevant } \\
\text { literature. }\end{array}$ & 1 & 2 & 3 & 4 & 5 & 6 & 7 \\
\hline 1 & 2 & 3 & 4 & 5 & 6 & 7 & $\begin{array}{l}\text { S17 - The student are given enough help related to the appropriateness of the form and } \\
\text { content of references. }\end{array}$ & 1 & 2 & 3 & 4 & 5 & 6 & 7 \\
\hline 1 & 2 & 3 & 4 & 5 & 6 & 7 & S18 - The student are given enough help related to the style and professional language. & 1 & 2 & 3 & 4 & 5 & 6 & 7 \\
\hline 1 & 2 & 3 & 4 & 5 & 6 & 7 & $\begin{array}{l}\begin{array}{l}\text { S19 - The consultant professionally supports the preparation for the oral presentation } \\
\text { of the project work. }\end{array}\end{array}$ & 1 & 2 & 3 & 4 & 5 & 6 & 7 \\
\hline 1 & 2 & 3 & 4 & 5 & 6 & 7 & S20 - The consultant is polite, responsive, attentive. & 1 & 2 & 3 & 4 & 5 & 6 & 7 \\
\hline 1 & 2 & 3 & 4 & 5 & 6 & 7 & S21 - The consultant is familiar with the administration process of project works. & 1 & 2 & 3 & 4 & 5 & 6 & 7 \\
\hline 1 & 2 & 3 & 4 & 5 & 6 & 7 & S22 - The student trusts the consultant and relies on his/her professional knowledge. & 1 & 2 & 3 & 4 & 5 & 6 & 7 \\
\hline 1 & 2 & 3 & 4 & 5 & 6 & 7 & $\begin{array}{l}\text { S23 - The content requirements of the project work are fulfilled due to the continuous } \\
\text { cooperation between the student and the consultant. }\end{array}$ & 1 & 2 & 3 & 4 & 5 & 6 & 7 \\
\hline 1 & 2 & 3 & 4 & 5 & 6 & 7 & S24 - There is a clear communication between the consultant and the student. & 1 & 2 & 3 & 4 & 5 & 6 & 7 \\
\hline 1 & 2 & 3 & 4 & 5 & 6 & 7 & S25 - There is a partnership between the student and the consultant. & 1 & 2 & 3 & 4 & 5 & 6 & 7 \\
\hline 1 & 2 & 3 & 4 & 5 & 6 & 7 & S26 - During the semester the student is given personal attention. & 1 & 2 & 3 & 4 & 5 & 6 & 7 \\
\hline
\end{tabular}

the particular field addressed by the statement, while the importance dimension is used to express how much they find important the addressed topic.

In order to understand the students' opinion about the quality of project work type courses, we surveyed students at different levels of courses both on bachelor and master levels. The evaluated courses and the levels of education for each course are summarized in Table 5 .
Cronbach-alpha is used to estimate the degree of reliability. Overall reliabilities were $\alpha=0.932$ and 0.95 respectively for the importance and performance scales. $\alpha=0.95$ was the overall reliability for both the importance - performance difference scores and importance $*$ performance scores. These reliability measures exceeded the usual recommendation of $\alpha=0.70$ for establishing internal consistency of the scale. 
Table 5 Response rate of the survey questionnaire

\begin{tabular}{|c|c|c|c|}
\hline Type of project work & Total number of students & Total number of filled questionnaires & Response rate \\
\hline Project work I. BA & 32 & 25 & $78.13 \%$ \\
\hline Project work II. BA & 203 & 118 & $58.13 \%$ \\
\hline Project work III. BA & 25 & 11 & $44.00 \%$ \\
\hline Project work I. MA & 64 & 56 & $87.50 \%$ \\
\hline Total & 324 & 210 & $64.81 \%$ \\
\hline Level of study & Total number of students & Total number of filled questionnaires & Response rate \\
\hline $\mathrm{BA} / \mathrm{BSc}$ level & 260 & 154 & $59.23 \%$ \\
\hline MA level & 64 & 56 & $87.50 \%$ \\
\hline Total & 324 & 210 & $64.81 \%$ \\
\hline Program & Total number of students & Total number of filled questionnaires & Response rate \\
\hline Engineering Management (BSc) & 91 & 59 & $64.84 \%$ \\
\hline Management and business administration (BA) & 89 & 49 & $55.06 \%$ \\
\hline International Business Economics (BA) & 80 & 46 & $57.50 \%$ \\
\hline Marketing (MA) & 64 & 56 & $87.50 \%$ \\
\hline Total & 324 & 210 & $64.81 \%$ \\
\hline
\end{tabular}

\section{Results}

The two-dimensional survey approach is built on the consideration that issues having higher importance scores should have higher performance values as students rightly may expect higher service level in the areas which they consider to be more important. The sum of importance and performance scores was calculated for each statement with the purpose of analyzing how the importance and performance categories relate to each other. Fig. 1 shows the total sum of importance scores and the total sum of performance scores for each statement. Fig. 1 also demonstrates that in case of about half of the statements the sum of performance scores exceed the sum of importance scores.
The next stage in the analysis was to examine the responses across the scale items to assess students' perceptions of service quality and the relative importance assigned by the respondents to each statement. Mean importance and mean performance scores are shown for each of the statements (see red lines in Fig. 2). One of the advantages of IPA is that service quality statements can be plotted graphically on a two-dimensional matrix to assist in quick and efficient interpretation of the results. Fig. 2 highlights the relative dimensions in a matrix format. The matrix is represented by the importance values on the vertical axis, while performance values are on the horizontal axis. Mean values represent the cross-hairs of the matrix to identify the stronger and weaker statements more clearly.

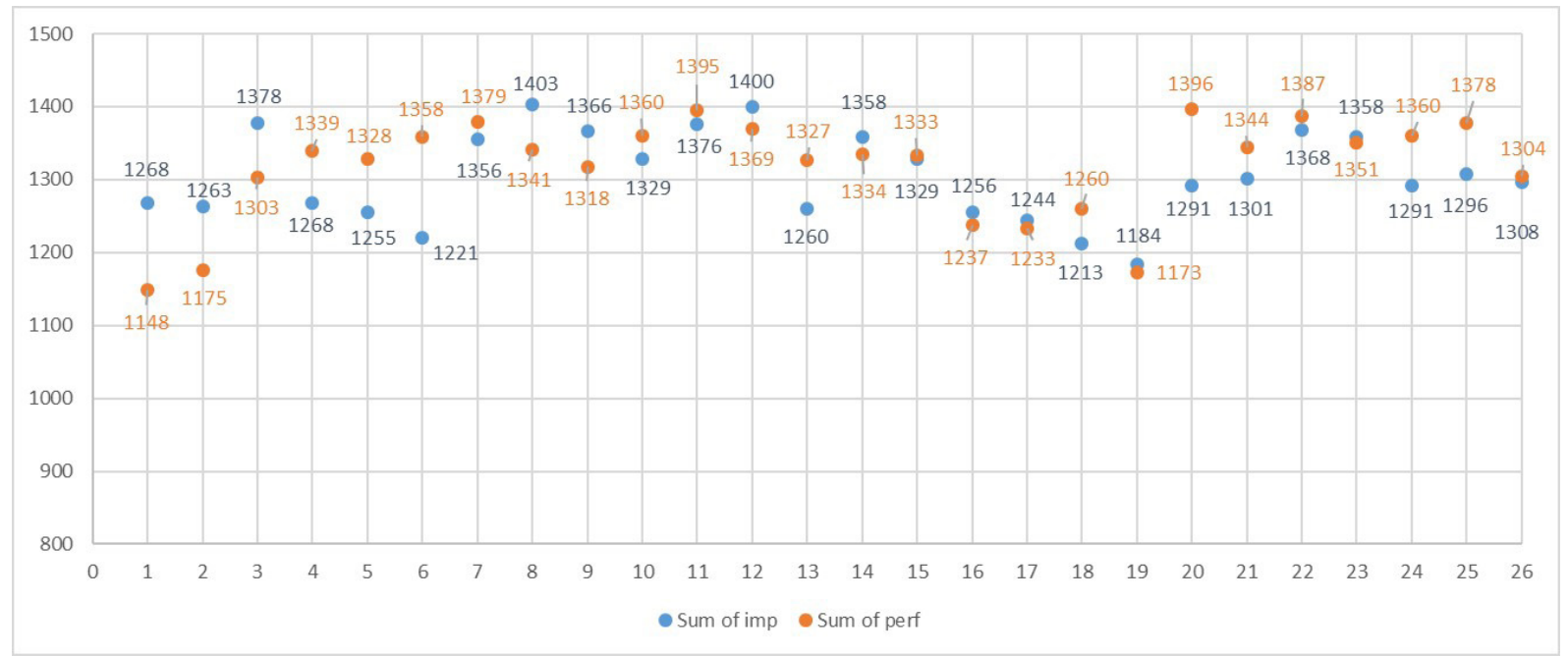

Fig. 1 Differences between sum of importance and sum of performance scores 


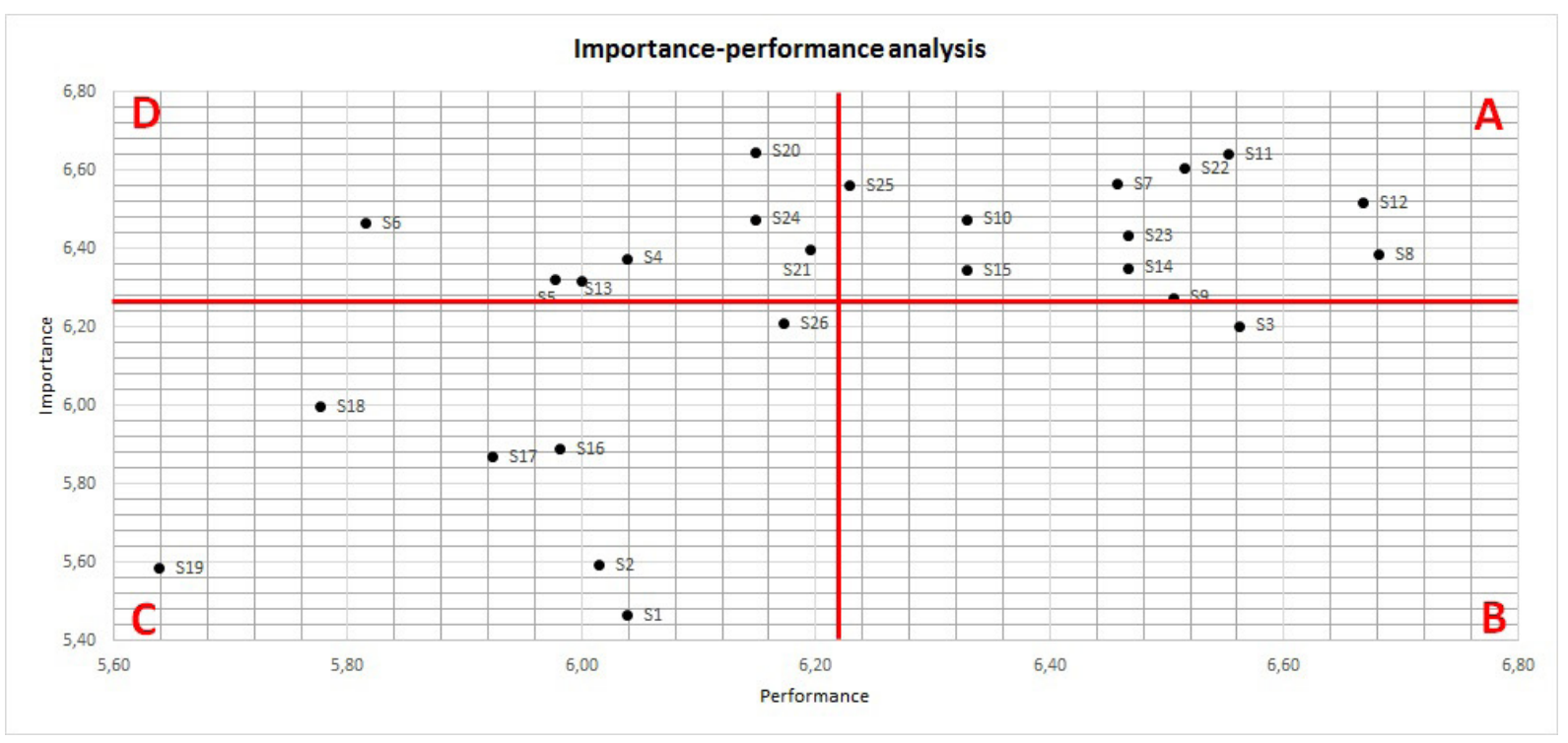

Fig. 2 Importance-performance map

Quadrant A including S7-S12, S14, S15, S22, S23, S25 is reflective of a level of optimal performance as lecturers are perceived to perform well above the average in relation to the delivery of those service quality aspects that are deemed important by the students. Quadrant B denotes a misuse of resources. In our case only one statement fell into this quadrant, namely, S3. Quadrant C including S1, S2, S16-S19, S26 represents those fields where improvement efforts are required as in case of these statements both the importance and performance scores are below the average. Quadrant D reflects those statements (S4S6, S13, S20, S21, S24) where lecturers do not perform to their full service potential.

The importance and performance scores can be considered as random variables, and so their averages can be taken as point estimates of their expected values. In addition to the result of IPA, Wilcoxon signed-rank tests (with related samples, $\alpha=5 \%$ ) were run to evaluate in case of which statements the median of differences between importance and performance scores differ significantly from zero. When the importance score differs significantly from the corresponding performance score in case of a particular statement, this is reflective of the existence of a quality performance gap. This in turn may be used to identify specific quality improvement efforts. Similarly, where performance scores do not differ significantly from the corresponding importance scores for a given statement, this may also strengthen exceptional performance and/or misdirected quality effort (see Table 6). Table 6 highlights those statements (S1-S6, S8-S10, S12, 13, S18,
Table 6 Results of Wilcoxon signed-rank tests $(\alpha=5 \%)$

\begin{tabular}{|c|c|c|}
\hline Statement & $t$-value & $p$-value \\
\hline S1 & 5.912 & 0.000 \\
\hline S2 & 4.718 & 0.000 \\
\hline S3 & 4.793 & 0.000 \\
\hline S4 & -4.093 & 0.000 \\
\hline S5 & -4.367 & 0.000 \\
\hline S6 & -6.148 & 0.000 \\
\hline S7 & -1.580 & 0.114 \\
\hline S8 & 4.670 & 0.000 \\
\hline S9 & 2.986 & 0.003 \\
\hline S10 & -2.142 & 0.032 \\
\hline S11 & -1.378 & 0.168 \\
\hline $\mathrm{S} 12$ & 2.200 & 0.028 \\
\hline $\mathrm{S} 13$ & -3.503 & 0.000 \\
\hline S14 & 1.331 & 0.183 \\
\hline S15 & -0.686 & 0.493 \\
\hline S16 & 0.507 & 0.612 \\
\hline S17 & 0.061 & 0.951 \\
\hline S18 & -2.821 & 0.005 \\
\hline S19 & 0.266 & 0.790 \\
\hline $\mathrm{S} 20$ & -5.612 & 0.000 \\
\hline $\mathrm{S} 21$ & -2.385 & 0.017 \\
\hline $\mathrm{S} 22$ & -1.228 & 0.220 \\
\hline S23 & -0.154 & 0.877 \\
\hline S24 & -4.584 & 0.000 \\
\hline S25 & -4.534 & 0.000 \\
\hline S26 & -0.452 & 0.652 \\
\hline
\end{tabular}


$\mathrm{S} 20,21, \mathrm{~S} 24,25)$ where $p$-values are lower than 0.05 , which means that in these cases the null hypotheses are rejected, therefore, the difference between performance and importance score pairs do not follow a symmetric distribution around zero.

Secondly, data was segmented according to the type of the program, namely, Engineering Management BSc, International Business Economics BA, Management and Business Administration BA and Marketing MA. The results of similarly conducted Wilcoxon signed-rank tests $(\alpha=5 \%)$ are summarized in Table 7 where those statements are highlighted again where the null hypotheses are rejected, that is, the differences between performance and importance score pairs do not follow a symmetric distribution around zero. Taking the types of programs into account, statement S6, S8 and S20 are the statements in case of which all null hypotheses were rejected, therefore significant differences between important and performance scores were revealed. Similarly to the previously detailed conclusions, Table 7 summarizes the results of same tests when data is segmented according to the level of study (see "BA level of study" and "Marketing (MA)" labeled columns of Table 7, note that only students of Marketing MA program were involved in this semester from our MA students (see Table 5)). If we take a look at the segmentation according to the levels of study, more statements (compared to the previously applied segmentation) show differences between importance-performance score pairs (S1-S4, S6, S8, S15, S20).

Table 8 includes the results of testing whether the distributions of importance and that of performance scores are the same across categories given separately by BA/BSc

Table 7 Results of Wilcoxon signed-rank tests $(\alpha=5 \%)$ - Data segmentation based on study programs and levels of study

\begin{tabular}{|c|c|c|c|c|c|c|c|c|c|c|}
\hline \multirow[t]{2}{*}{$\begin{array}{l}\text { Number of } \\
\text { statement }\end{array}$} & \multicolumn{2}{|c|}{$\begin{array}{l}\text { Engineering } \\
\text { Management } \\
\quad(\mathrm{BSc})\end{array}$} & \multicolumn{2}{|c|}{$\begin{array}{c}\text { International } \\
\text { Business } \\
\text { Economics (BA) }\end{array}$} & \multicolumn{2}{|c|}{$\begin{array}{c}\text { Management } \\
\text { and Business } \\
\text { Administration (BA) }\end{array}$} & \multicolumn{2}{|c|}{ BA level of study } & \multicolumn{2}{|c|}{ Marketing (MA) } \\
\hline & $t$-value & $p$-value & $t$-value & $p$-value & $t$-value & $p$-value & $t$-value & $p$-value & $t$-value & $p$-value \\
\hline S1 & 3.751 & 0.000 & 2.215 & 0.027 & 1.819 & 0.069 & 4.480 & 0.000 & 3.853 & 0.000 \\
\hline S2 & 3.196 & 0.001 & 2.076 & 0.038 & 1.695 & 0.090 & 4.038 & 0.000 & 2.415 & 0.016 \\
\hline S3 & 1.842 & 0.066 & 2.790 & 0.005 & 1.615 & 0.106 & 3.580 & 0.000 & 3.388 & 0.001 \\
\hline S4 & -2.805 & 0.005 & -0.526 & 0.599 & -2.130 & 0.033 & -3.347 & 0.001 & -2.391 & 0.017 \\
\hline S5 & -3.214 & 0.001 & -1.148 & 0.251 & -3.347 & 0.001 & -4.508 & 0.000 & -0.981 & 0.326 \\
\hline S6 & -3.950 & 0.000 & -2.360 & 0.018 & -2.000 & 0.045 & -5.058 & 0.000 & -3.463 & 0.001 \\
\hline S7 & -1.850 & 0.064 & 1.427 & 0.154 & -1.186 & 0.236 & -1.322 & 0.186 & -0.908 & 0.364 \\
\hline S8 & 2.552 & 0.011 & 2.275 & 0.023 & 2.222 & 0.026 & 4.044 & 0.000 & 2.304 & 0.021 \\
\hline S9 & 0.793 & 0.428 & 1.986 & 0.047 & 1.495 & 0.135 & 2.426 & 0.015 & 1.718 & 0.086 \\
\hline S10 & -2.362 & 0.018 & -1.462 & 0.144 & -0.256 & 0.798 & -2.345 & 0.019 & -0.085 & 0.933 \\
\hline S11 & -1.774 & 0.076 & 1.153 & 0.249 & -0.575 & 0.565 & -0.981 & 0.327 & -1.035 & 0.301 \\
\hline S12 & 0.730 & 0.465 & 0.120 & 0.904 & 1.852 & 0.064 & 1.505 & 0.132 & 1.745 & 0.081 \\
\hline S13 & -1.389 & 0.165 & -3.108 & 0.002 & -1.990 & 0.047 & -3.604 & 0.000 & -0.704 & 0.481 \\
\hline S14 & 0.663 & 0.507 & 1.320 & 0.187 & -0.941 & 0.347 & 0.732 & 0.464 & 1.515 & 0.130 \\
\hline S15 & -1.379 & 0.168 & -1.453 & 0.146 & -1.294 & 0.196 & -2.343 & 0.019 & 2.058 & 0.040 \\
\hline S16 & 0.015 & 0.988 & -1.166 & 0.244 & 2.025 & 0.043 & 0.007 & 0.994 & 1.045 & 0.296 \\
\hline S17 & -1.724 & 0.085 & 0.280 & 0.780 & 1.702 & 0.089 & 0.065 & 0.948 & 0.050 & 0.960 \\
\hline S18 & -2.483 & 0.013 & -1.442 & 0.149 & 0.085 & 0.933 & -2.540 & 0.011 & -1.266 & 0.205 \\
\hline S19 & 0.368 & 0.713 & -0.568 & 0.570 & -0.049 & 0.961 & -0.116 & 0.907 & 0.671 & 0.502 \\
\hline S20 & -3.147 & 0.002 & -2.865 & 0.004 & -2.857 & 0.004 & -5.082 & 0.000 & -2.409 & 0.016 \\
\hline S21 & -2.281 & 0.023 & -1.395 & 0.163 & -2.080 & 0.037 & -3.355 & 0.001 & 0.806 & 0.420 \\
\hline $\mathrm{S} 22$ & -1.389 & 0.165 & 0.714 & 0.475 & -1.186 & 0.236 & -1.089 & 0.276 & -0.560 & 0.576 \\
\hline $\mathrm{S} 23$ & -1.252 & 0.210 & -0.601 & 0.548 & 0.625 & 0.532 & -0.855 & 0.392 & 1.220 & 0.223 \\
\hline $\mathrm{S} 24$ & -2.675 & 0.007 & -2.543 & 0.011 & -2.368 & 0.018 & -4.344 & 0.000 & -1.793 & 0.073 \\
\hline $\mathrm{S} 25$ & -2.480 & 0.013 & -2.790 & 0.005 & -2.568 & 0.010 & -4.456 & 0.000 & -1.435 & 0.151 \\
\hline S26 & -0.416 & 0.678 & -1.231 & 0.218 & -0.295 & 0.768 & -0.973 & 0.330 & 0.463 & 0.643 \\
\hline
\end{tabular}


Table 8 Results of Mann Whitney U tests $(\alpha=5 \%)$ - Data segmentation based on levels of study

\begin{tabular}{|c|c|c|c|c|}
\hline \multirow{2}{*}{$\begin{array}{l}\text { Number of } \\
\text { statement }\end{array}$} & \multicolumn{2}{|c|}{ Diff. Imp. BA-MA } & \multicolumn{2}{|c|}{ Diff. Perf. BA-MA } \\
\hline & $t$-value & $p$-value & $t$-value & $p$-value \\
\hline $\mathrm{S} 1$ & -0.319 & 0.750 & 1.354 & 0.176 \\
\hline S2 & 1.013 & 0.311 & 0.673 & 0.501 \\
\hline S3 & -0.326 & 0.744 & -0.638 & 0.523 \\
\hline S4 & 0.710 & 0.478 & 0.165 & 0.869 \\
\hline S5 & -2.074 & 0.038 & -0.973 & 0.331 \\
\hline S6 & 0.520 & 0.603 & -0.939 & 0.348 \\
\hline S7 & 0.017 & 0.987 & -0.883 & 0.377 \\
\hline S8 & -0.254 & 0.799 & -1.026 & 0.305 \\
\hline S9 & -0.121 & 0.903 & 0.191 & 0.848 \\
\hline S10 & -1.331 & 0.183 & -0.164 & 0.870 \\
\hline S11 & -0.255 & 0.799 & -0.938 & 0.348 \\
\hline $\mathrm{S} 12$ & -2.044 & 0.041 & -0.592 & 0.554 \\
\hline S13 & -1.232 & 0.218 & 0.521 & 0.602 \\
\hline S14 & -0.606 & 0.544 & -0.081 & 0.935 \\
\hline S15 & -1.507 & 0.132 & 1.314 & 0.189 \\
\hline S16 & -2.675 & 0.007 & -1.388 & 0.165 \\
\hline S17 & -1.620 & 0.105 & -1.861 & 0.063 \\
\hline $\mathrm{S} 18$ & -0.938 & 0.348 & -0.944 & 0.345 \\
\hline S19 & -1.724 & 0.085 & -0.908 & 0.364 \\
\hline S20 & -0.545 & 0.586 & -0.545 & 0.586 \\
\hline S21 & -1.079 & 0.280 & 1.315 & 0.188 \\
\hline S22 & -0.564 & 0.572 & -0.267 & 0.789 \\
\hline S23 & 0.410 & 0.682 & 1.793 & 0.073 \\
\hline S24 & -0.978 & 0.328 & -0.869 & 0.385 \\
\hline S25 & -1.731 & 0.083 & -1.023 & 0.306 \\
\hline S26 & -1.037 & 0.300 & -0.610 & 0.542 \\
\hline
\end{tabular}

and MA students applying Mann-Whitney U tests $(\alpha=5$ $\%$ ). Table 8 demonstrates that the null hypotheses were rejected in case of importance scores of S5, S12 and S16, while for performance scores the distributions were found to be the same for all statements.

The results were also segmented based not only according to the characteristics of students, but also to the distinctive features of the department, the different types of project works and the different types of programs. Table 9 consists of the results of Kruskal Wallis tests $(\alpha=5 \%)$ testing whether the distribution of performance and importance scores is the same across categories segmented according to the different subgroups of the department. In case of S1 and S25 significant differences were found between the performance scores based on this type of segmentation. Table 10 shows the results of Kruskal Wallis tests $(\alpha=5 \%)$ when evaluations are
Table 9 Results of Kruskal Wallis tests $(\alpha=5 \%)$ separately for importance and performance score - Data segmentation based on the subgroups of the department

\begin{tabular}{|c|c|c|c|c|}
\hline \multirow{2}{*}{ Statement } & \multicolumn{2}{|c|}{ Performance } & \multicolumn{2}{|c|}{ Importance } \\
\hline & $t$-value & $p$-value & $t$-value & $p$-value \\
\hline S1 & 8.958 & 0.030 & 2.687 & 0.442 \\
\hline S2 & 3.266 & 0.352 & 6.411 & 0.093 \\
\hline S3 & 2.488 & 0.477 & 5.503 & 0.138 \\
\hline S4 & 0.899 & 0.826 & 3.869 & 0.276 \\
\hline S5 & 3.470 & 0.325 & 5.644 & 0.130 \\
\hline S6 & 4.643 & 0.200 & 0.786 & 0.853 \\
\hline S7 & 2.730 & 0.435 & 1.611 & 0.657 \\
\hline S8 & 0.961 & 0.811 & 4.025 & 0.259 \\
\hline S9 & 3.369 & 0.338 & 6.946 & 0.074 \\
\hline S10 & 1.340 & 0.720 & 3.806 & 0.283 \\
\hline S11 & 1.278 & 0.734 & 2.256 & 0.521 \\
\hline S12 & 0.902 & 0.825 & 3.373 & 0.338 \\
\hline S13 & 0.309 & 0.958 & 0.071 & 0.995 \\
\hline S14 & 2.257 & 0.521 & 2.172 & 0.537 \\
\hline S15 & 1.098 & 0.778 & 7.326 & 0.062 \\
\hline S16 & 4.053 & 0.256 & 2.285 & 0.515 \\
\hline S17 & 3.914 & 0.271 & 2.214 & 0.529 \\
\hline S18 & 3.293 & 0.349 & 0.860 & 0.835 \\
\hline S19 & 1.534 & 0.674 & 0.688 & 0.876 \\
\hline S20 & 2.096 & 0.553 & 0.801 & 0.849 \\
\hline S21 & 3.344 & 0.342 & 2.218 & 0.528 \\
\hline $\mathrm{S} 22$ & 0.699 & 0.874 & 0.705 & 0.872 \\
\hline S23 & 0.377 & 0.945 & 1.569 & 0.666 \\
\hline S24 & 6.751 & 0.080 & 2.782 & 0.427 \\
\hline S25 & 8.321 & 0.040 & 5.689 & 0.128 \\
\hline S26 & 3.504 & 0.320 & 3.095 & 0.377 \\
\hline
\end{tabular}

segmented according to the type of project work course, namely Project work I. BA/BSc, Project work II. BA/BSc, Project work III. BA and Project work I. MA. According to the test results, significant differences were found between the distribution of importance scores for $\mathrm{S} 3$, S4, S12, S15 and S16, and for the distribution of performance scores for S7, S12 and S15. Table 11 demonstrates the results of Kruskal Wallis tests $(\alpha=5 \%)$ when data is segmented based on the study programs. In these cases significant differences were detected between the distribution of importance scores across categories for S4, S14 and S16, while performance distributions are proved to be the same for all statements.

If we take all the aforementioned statistical analysis and the comparison of importance and performance scores into consideration the statements which require 
Table 10 Results of Kruskal Wallis tests ( $\alpha=5 \%$ ) separately for importance and performance score - Data segmentation based on the type of project work course

\begin{tabular}{|c|c|c|c|c|}
\hline \multirow{2}{*}{ Statement } & \multicolumn{2}{|c|}{ Performance } & \multicolumn{2}{|c|}{ Importance } \\
\hline & $t$-value & $p$-value & $t$-value & $p$-value \\
\hline $\mathrm{S} 1$ & 5.700 & 0.127 & 4.352 & 0.226 \\
\hline S2 & 6.992 & 0.072 & 5.009 & 0.171 \\
\hline S3 & 7.386 & 0.061 & 15.220 & 0.002 \\
\hline $\mathrm{S} 4$ & 6.750 & 0.080 & 20.142 & 0.000 \\
\hline S5 & 5.189 & 0.158 & 5.769 & 0.123 \\
\hline S6 & 3.724 & 0.293 & 2.646 & 0.449 \\
\hline S7 & 9.209 & 0.027 & 2.116 & 0.549 \\
\hline S8 & 5.567 & 0.135 & 5.251 & 0.154 \\
\hline S9 & 5.210 & 0.157 & 6.133 & 0.105 \\
\hline $\mathrm{S} 10$ & 5.435 & 0.143 & 5.405 & 0.144 \\
\hline S11 & 4.929 & 0.177 & 3.072 & 0.381 \\
\hline $\mathrm{S} 12$ & 9.357 & 0.025 & 18.830 & 0.000 \\
\hline $\mathrm{S} 13$ & 4.333 & 0.228 & 6.028 & 0.110 \\
\hline S14 & 4.171 & 0.244 & 5.851 & 0.119 \\
\hline S15 & 14.123 & 0.003 & 11.950 & 0.008 \\
\hline S16 & 4.618 & 0.202 & 10.338 & 0.016 \\
\hline S17 & 6.163 & 0.104 & 6.033 & 0.110 \\
\hline S18 & 6.258 & 0.100 & 7.286 & 0.063 \\
\hline S19 & 6.037 & 0.110 & 5.285 & 0.152 \\
\hline S20 & 1.536 & 0.674 & 2.711 & 0.438 \\
\hline S21 & 7.179 & 0.066 & 4.813 & 0.186 \\
\hline S22 & 4.590 & 0.204 & 6.584 & 0.086 \\
\hline S23 & 5.737 & 0.125 & 2.961 & 0.398 \\
\hline S24 & 5.548 & 0.136 & 6.034 & 0.110 \\
\hline S25 & 6.841 & 0.077 & 4.514 & 0.211 \\
\hline S26 & 3.203 & 0.361 & 5.508 & 0.138 \\
\hline
\end{tabular}

deeper analysis are S1-S4, S6, S8 and S20. The results of importance score comparisons call attention primarily for statements S4, S12 and S16, and that of performance score comparisons for statements S7, S12, S15 and S25.

Taking all the aforementioned segmentations into account Spearman's rho measures have been applied to analyze the association between variables of ordinal measurement levels by calculating the Pearson correlation for variables that are converted to ranks. Table 12 summarized the value of rank-order coefficients measured between the importance ranking and performance ranking of statements following the previously applied segmentations.

To determine whether the correlations between importance and performance rankings as variables are significant, the $p$-values are compared to our significance level $(0.05)$. Taking all applied classifications into account, the
Table 11 Results of Kruskal Wallis tests $(\alpha=5 \%$ ) separately for importance and performance score - Data segmentation based on the type of study program

\begin{tabular}{|c|c|c|c|c|}
\hline \multirow{2}{*}{ Statement } & \multicolumn{2}{|c|}{ Performance } & \multicolumn{2}{|c|}{ Importance } \\
\hline & $t$-value & $p$-value & $t$-value & $p$-value \\
\hline S1 & 4.947 & 0.293 & 1.178 & 0.758 \\
\hline S2 & 3.318 & 0.506 & 1.426 & 0.699 \\
\hline S3 & 1.875 & 0.759 & 1.282 & 0.733 \\
\hline S4 & 4.217 & 0.377 & 8.442 & 0.038 \\
\hline S5 & 2.045 & 0.727 & 7.063 & 0.070 \\
\hline S6 & 1.558 & 0.816 & 3.847 & 0.278 \\
\hline S7 & 2.011 & 0.734 & 3.259 & 0.353 \\
\hline S8 & 7.261 & 0.123 & 3.460 & 0.326 \\
\hline S9 & 2.490 & 0.646 & 0.604 & 0.896 \\
\hline S10 & 0.865 & 0.929 & 3.386 & 0.336 \\
\hline S11 & 3.204 & 0.524 & 2.107 & 0.550 \\
\hline S12 & 5.348 & 0.253 & 5.813 & 0.121 \\
\hline S13 & 5.531 & 0.237 & 3.079 & 0.380 \\
\hline S14 & 1.105 & 0.893 & 8.615 & 0.035 \\
\hline S15 & 2.819 & 0.589 & 2.396 & 0.494 \\
\hline S16 & 3.851 & 0.427 & 11.355 & 0.010 \\
\hline S17 & 6.323 & 0.176 & 4.454 & 0.216 \\
\hline S18 & 4.082 & 0.395 & 2.527 & 0.470 \\
\hline S19 & 3.804 & 0.433 & 3.895 & 0.273 \\
\hline S20 & 5.566 & 0.234 & 4.423 & 0.219 \\
\hline S21 & 4.334 & 0.363 & 3.846 & 0.279 \\
\hline S22 & 0.941 & 0.919 & 1.650 & 0.648 \\
\hline $\mathrm{S} 23$ & 4.331 & 0.363 & 1.416 & 0.702 \\
\hline S24 & 1.623 & 0.805 & 1.970 & 0.579 \\
\hline $\mathrm{S} 25$ & 4.270 & 0.371 & 4.074 & 0.254 \\
\hline S26 & 5.008 & 0.286 & 3.017 & 0.389 \\
\hline
\end{tabular}

correlations between the rankings of statements based on the sum of importance and performance scores show at least moderate positive relationship. In case of some specific segments the correlations indicate quite large positive relationships (values higher than 0.7). As all $p$-values in Table 12 are less than the significance level of 0.05 , all correlations are statistically significant.

\section{Conclusions and managerial implications}

In this paper the application of a questionnaire including 26 statements and the first results of statistical analysis were presented in order to measure and evaluate the service quality dimensions of courses with consultation processes and via that the voice of students. The novelty of the paper may be apprehended on two threads. Firstly, a modified and more sophisticated questionnaire was applied 
Table 12 Spearman rank-order correlations $(\alpha=5 \%)$

\begin{tabular}{lcc}
\hline Segment & Spearman rank correlation & $\boldsymbol{p}$-value \\
\hline All students & 0.508 & 0.008 \\
Project work I. BA & 0.44 & 0.024 \\
Project work II. BA & 0.512 & 0.007 \\
Project work III. BA & 0.716 & 0 \\
Project work I. MA & 0.461 & 0.018 \\
Marketing subgroup & 0.489 & 0.011 \\
Quality management subgroup & 0.733 & 0 \\
International Business Economics & 0.86 & 0 \\
Management and business administration & 0.578 & 0.002 \\
Engineering management & 0.468 & 0.016 \\
Marketing (MA level) & 0.45 & 0.021 \\
BA/BSc level & 0.562 & 0.003 \\
\hline
\end{tabular}

compared to the one in use at the university with the aim of getting a deeper knowledge of student satisfaction related to consultation processes by extending the aspects with particular viewpoints. Secondly, the traditional survey was extended with the measurement of the statements' importance from the students' viewpoint.

The main limitation of the research is that the statistical analyses presented in this paper are based on a one semester-long performance. The primary aim of future research directions is to extend the presented measurement and evaluation process to the next semester as e.g. BA students usually have at least two or three consequent project work courses. Taking the specialties of the fall and spring semesters into account, the analyzed fall semester results were formulated mainly on students completing the Project work II. BA course and Project work I. MA course as most of the students follow the sample curriculum. By extending the analysis to the spring semester as well, the reliability of statistical analyses may be enhanced, and more reliable samples may be taken from the different segments utilized for classification in this paper. Our extensive statistical analyses strengthen the null hypotheses were accepted in most of the cases. We highlighted in each segmentation those statements where the null hypotheses were rejected on the given significance level of 0.05 .

By following up with this questionnaire and these methods, the results of two semesters would provide the opportunity to adapt specific quality management methods to decrease the gap between the importance and performance scores in those cases where performance scores were lower than the average. After the second semester involved in the analysis brainstorming sessions with the involvement of different groups of students are to be organized in order to offer students the opportunity to give narrative comments related to the critical to quality (CTQ) statements. After the brainstorming session, ideas may be grouped into an affinity diagram the results of which could be utilized as inputs for constructing cause and effect diagrams to investigate the root causes of lower performance. In the light of the continuous improvement philosophy and following the PDCA cycle of course evaluation (see e.g. Venkatraman, 2007), improving actions could be identified in order to further enhance the performance of consultation processes.

It is also important to note that we had to face with the difficulties particularly arising from the application of traditional Likert scales. Students are usually not given such a questionnaire during their studies, for most of them this was the first time to express their judgement in this way by rating both the importance and performance of a given attribute. Taking into account the average importance values, they gave relatively high scores for all statements.

In case of the Likert scale applied in our questionnaire the number of "values" to choose from is small which means that the variability, diversity and subjectivity associated with an accurate rating is usually lost (Gil and González-Rodríguez, 2012). Another disadvantage of traditional Likert scales originates from the fact that when values are encoded by their relative position in accordance with a certain ranking, differences between codes cannot be interpreted as differences in their magnitude. It means that only statistical conclusions addressed to ordinal data can be reliable and relevant information can be lost (Lubiano et al., 2016). Another major issue related to the application of Likert scales is the weighting of aspects as they are usually not equally important for the raters. 
Average scores are supposed to hide the real situation, namely, the performance of the rated item (Kuzmanovic et al., 2013). Moreover, when Likert-type data are investigated for statistical purposes, the techniques to analyze them are quite limited (Lubiano et al., 2016). Different studies have been carried out to discuss the reliability of the analysis of these responses pointing out that increasing the number of responses results in an increase of information and reliability (de la Rosa de Sáa et al., 2015; Lozano et al., 2008). However, it cannot be achieved by using a natural language (Sowa, 2013). To manage these disadvantages there is an alternate approach utilizing fuzzy numbers which takes into account that the nature of most attributes related to evaluations, judgements involve subjectivity and certain imprecision (Lubiano et al., 2016; Quirós et al., 2016). Fuzzy numbers can deal with a challenging problem which is related to how to handle properly the inherent uncertainty of human perceptions.
By providing a fuzzy Likert scale to evaluate performance, students can express their uncertainty, their contrasting perceptions and the variability of performance in a quantitative way (Jónás et al., 2017; Tóth et al., 2017).

Another important aim is the revision of the questionnaire as HEIs should carry out extensive research in order to identify those factors that are considered to be highly important for students in their evaluations of service experience. Based on the results of the first semester given by students in both dimensions, principal component analyses (PCA) were also conducted for the importance, performance and importance * performance values using varimax rotation in keeping with the original SERVQUAL study (Parasuraman et al., 1985) and other studies to examine the underlying factors and dimensions that could not be measured. Table 13 presents the rotated component matrix for the importance values (the value of the Kaiser-Meyer-Olkin Measure of Sampling Adequacy

Table 13 Rotated Component Matrix

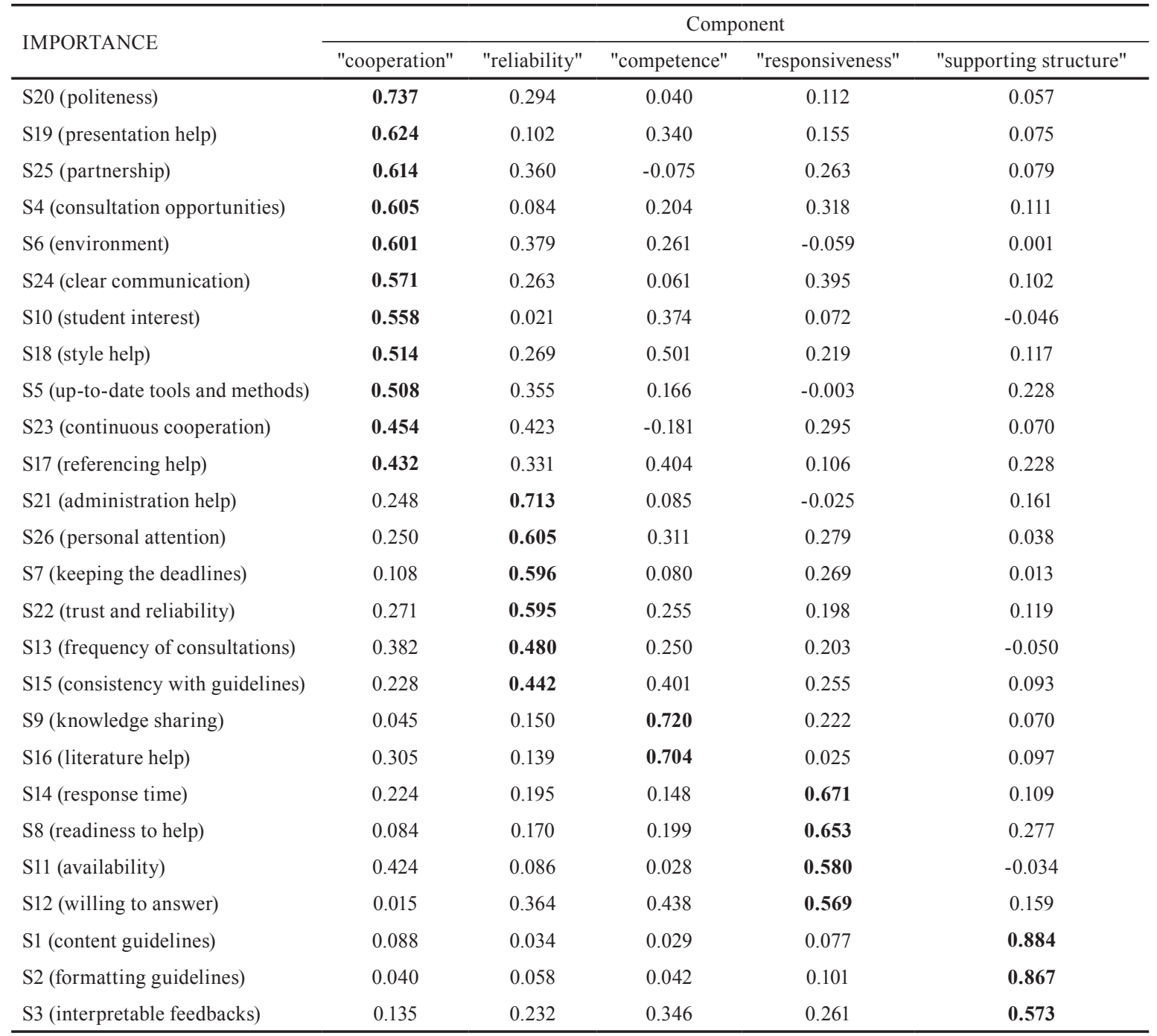


Table 14 Total variance explained by five components

\begin{tabular}{cccccccccc}
\hline \multicolumn{10}{c}{ Total Variance Explained } \\
\hline \multirow{2}{*}{ Component } & \multicolumn{3}{c}{ Initial Eigenvalues } & \multicolumn{2}{c}{ Extraction Sums of Squared Loadings } & \multicolumn{3}{c}{ Rotation Sums of Squared Loadings } \\
\cline { 2 - 10 } & Total & \% of Variance & Cumulative \% & Total & \% of Variance & Cumulative \% & Total & \% of Variance & Cumulative \% \\
\hline 1 & 9.386 & 36.099 & 36.099 & 9.386 & 36.099 & 36.099 & 4.358 & 16.761 & 16.761 \\
2 & 1.950 & 7.499 & 43.598 & 1.950 & 7.499 & 43.598 & 3.251 & 12.505 & 29.266 \\
3 & 1.353 & 5.202 & 48.801 & 1.353 & 5.202 & 48.801 & 2.641 & 10.157 & 39.422 \\
4 & 1.219 & 4.689 & 53.489 & 1.219 & 4.689 & 53.489 & 2.485 & 9.559 & 48.982 \\
5 & 1.034 & 3.976 & $\mathbf{5 7 . 4 6 5}$ & 1.034 & 3.976 & 57.465 & 2.206 & 8.483 & 57.465 \\
\hline
\end{tabular}

is 0.905$)$. Table 14 demonstrates proportion of the total variation $(57.465 \%)$ that can be explained by the identified factors. In case of importance values representing somehow the expectations of students, PCA resulted in five components, namely, cooperation, reliability, competence, responsiveness and supporting structure (and so in the case of the other two PCAs for performance and performance $*$ importance values). This analysis revealed that the five-component dimension proposed by Parasuraman et al. (1988) may be supported, but with a different factor structure compared to the original SERVQUAL. This may be explained by the fact that the questionnaire applied for our purposes deviated from the original SERVQUAL questionnaire in the interests of the special features of the surveyed courses. In the context of the relevant educational experience, the first component seems to relate to the semester-long cooperation between the consultant and the student. The second and fourth components are largely reflective on the Reliability and Responsiveness

\section{References}

Abdullah, F. (2006a) "Measuring service quality in higher education: HEdPERF versus SERVPERF", Marketing Intelligence \& Planning, 24(1), pp. 31-47. https://doi.org/10.1108/02634500610641543

Abdullah, F. (2006b) "The development of HEdPERF: a new measuring instrument of service quality for the higher education sector", International Journal of Consumer Studies, 30(6), pp. 569-581. https://doi.org/10.1111/j.1470-6431.2005.00480.x

Aldridge, S., Rowley, J. (1998) "Measuring customer satisfaction in higher education", Quality Assurance in Education, 6(4), pp. 197-204. https://doi.org/10.1108/09684889810242182

Alves, H., Raposo, M. (2009) "The measurement of the construct satisfaction in higher education", The Service Industries Journal, 29(2), pp. 203-218.

https://doi.org/10.1080/02642060802294995

Aly, N., Akpovi, J. (2001) "Total quality management in California public higher education", Quality Assurance in Education, 9(3), pp. $127-131$.

https://doi.org/10.1108/09684880110399077 dimensions of the original SERVQUAL. The third component ("competence") reflects the professional knowledge and the knowhow provided by the lecturers. The last component is labeled as "supporting structure" embodying specific tangibles of the service process. It also should be noted that this is an exploratory study and further data collection and analysis will seek to establish whether a consistent pattern of importance and performance ratings occur. Based on the second semester's data we intend to repeat these kinds of analyses in order to revise the number and content of the applied statements and make more reliable decisions when thinking about the revision of the questionnaire. It is also an open question whether students' perceptions and importance ratings for specific attributes grabbed in the form of statements change over time.

\section{Acknowledgement}

Supported by the ÚNKP-17-3-I. New National Excellence Program of the Ministry of Human Capacities.

Andersson, P. H., Hussmann, P. M., Jensen, H. E. (2009) "Doing the right things right : Quality enhancement in Higher Education", presented at SEFI 2009 Annual Conference, 37th Annual conference of the European Society for Engineering Education, Rotterdam, Netherlands, July 01, 2009.

Arokiasamy, A. R. A. (2012) "Literature review: service quality in higher education institutions in Malaysia", Contemporary Business Studies, 3(4), pp. 227-244.

Athiyaman, A. (1997) "Linking student satisfaction and service quality perceptions: the case of university education", European Journal of Marketing, 31(7), pp. 528-540. https://doi.org/10.1108/03090569710176655

Bala, N., Sandhu, H. S., Nagpal, N. (2011) "Measuring Life Insurance Service Quality: An Empirical Assessment of SERVQUAL Instrument", International Business Research, 4(4), pp. 176-190. [online] Available at: http://citeseerx.ist.psu.edu/viewdoc/download?doi=10.1.1.901.830\&rep=rep1\&type $=$ pdf $\quad$ [Accessed: 07 March 2018] 
Bedzsula, B., Kövesi, J. (2016) "Feedback of student course evaluation measurements to the budgeting process of a faculty. Case study of the Budapest University of Technology and Economics Faculty of Economic and Social Sciences", In: Dahlgaard-Park, S. M., Dahlgaard, J. J. (eds.) 19th QMOD-ICQSS Conference International Conference on Quality and Service Sciences, pp. 216-228.

Bedzsula, B., Topár, J. (2014) "Minőségmenedzsment szemlélet és eszközök szerepe a felsőoktatás fejlesztésében" (The role of quality management approach and tools in the development of higher education), Magyar Minöség, 23(3), pp. 34-47. (in Hungarian) [online] Available at: https:/quality-mmt.hu/wp-content/uploads/2016/06/2014_03_ MM.pdf [Accessed: 07 March 2018]

Bemowski, K. (1991) "Restoring the Pillars of Higher Education", Quality Progress, 24(10), pp. 37-42.

Bérces, R. (2015) "The Improvement of Higher Education Quality and Talent - Nurturing with Scientifics Students' Association (SSA) Commitment", Acta Polytechnica Hungarica, 12(5), pp. 101-120. https://doi.org/10.12700/APH.12.5.2015.5.6

Bhuian, S. N. (2016) "Sustainability of Western branch campuses in the Gulf Region: Students' perspectives of service quality", International Journal of Educational Development, 49, pp. 314-323. https://doi.org/10.1016/j.ijedudev.2016.05.001

Borahan, N. G., Ziarati, R. (2002) "Developing Quality Criteria for Application in the Higher Education Sector in Turkey", Total Quality Management, 13(7), pp. 913-926. https://doi.org/10.1080/0954412022000017021

Boulding, W., Kalra, A., Staelin, R., Zeithaml, V. A. (1993) "A Dynamic Process Model of Service Quality: From Expectations to Behavioral Intention", Journal of Marketing Research, 30(1), pp. 7-27. https://doi.org/10.2307/3172510

Bourner, T. (1998) "More knowledge, new knowledge: the impact on education and training", Education + Training, 40(1), pp. 11-14. https://doi.org/10.1108/00400919810203535

Brennan, J., Williams, R. (2004) "Collecting and using student feedback. A guide to good practice", [pdf] Learning and Teaching Support Network (LTSN), The Network Centre, Innovation Close, York Science Park, York, United Kingdom. Available at: https://www.heacademy.ac.uk/system/files/id352_collecting_ and_using_student_feedback_a_guide_to_good_practice.pdf [Accessed: 07 March 2018]

Brochado, A. (2009) "Comparing alternative instruments to measure service quality in higher education", Quality Assurance in Education, 17(2), pp. 174-190. https://doi.org/10.1108/09684880910951381

Çelik, A. K., Oktay, E., Özen, Ü., Karaaslan, A., Yarbaşi, İ. Y. (2018) "Assessing Postgraduate Students' Satisfaction with Quality of Services at a Turkish University Using Alternate Ordered Response Models", Periodica Polytechnica Social and Management Sciences, 26(1), pp. 87-101. https://doi.org/10.3311/PPso.9611

Chen, S.-H. (2011) "A performance matrix for strategies to improve satisfaction among faculty members in higher education", Quality \& Quantity, 45(1), pp. 75-89.

https://doi.org/10.1007/s11135-009-9291-2
Cheng, Y. C., Tam, W. M. (1997) "Multi-models of quality in education", Quality Assurance in Education, 5(1), pp. 22-31. https://doi.org/10.1108/09684889710156558

Chong, Y. S., Ahmed, P. K. (2012) "An empirical investigation of students' motivational impact upon university service quality perception: a self-determination perspective", Quality in Higher Education, 18(1), pp. 35-57. https://doi.org/10.1080/13538322.2012.667261

Clewes, D. (2003) "A Student-centred Conceptual Model of Service Quality in Higher Education", Quality in Higher Education, 9(1), pp. 69-85. https://doi.org/10.1080/1353832032000085467

Cronin, J. J., Taylor, S. A. (1992) "Measuring Service Quality: A Reexamination and Extension", Journal of Marketing, 56(3), pp. 55-68. https://doi.org/10.2307/1252296

Cuthbert, P. F. (1996a) "Managing service quality in HE: is SERVQUAL the answer? Part 1", Managing Service Quality: An International Journal, 6(2), pp. 11-16. https://doi.org/10.1108/09604529610109701

Cuthbert, P. F. (1996b) "Managing service quality in HE: is SERVQUAL the answer? Part 2", Managing Service Quality: An International Journal, 6(3), pp. 31-35. https://doi.org/10.1108/09604529610115858

Dale, B. G. (2003) "Managing Quality", 4th ed., Blackwell Publishing, Oxford, United Kingdom.

de la Rosa de Sáa, S., Gil, M. A., González-Rodríguez, G., López, M. T., Lubiano, M. A. (2015) "Fuzzy Rating Scale-Based Questionnaires and Their Statistical Analysis", IEEE Transactions on Fuzzy Systems, 23(1), pp. 111-126. https://doi.org/10.1109/TFUZZ.2014.2307895

DeShields Jr., O. W., Kara, A., Kaynak, E. (2005) "Determinants of business student satisfaction and retention in higher education: applying Herzberg's two factor theory", International Journal of Educational Management, 19(2), pp. 128-139. https://doi.org/10.1108/09513540510582426

Donaldson, B., Runciman, F. (1995) "Service quality in further education: An insight into management perceptions of service quality and those of the actual service provider", Journal of Marketing Management, 11(1-3), pp. 243-256. https://oi.org/10.1080/0267257X.1995.9964340

Entwistle, N., Tait, H. (1990) "Approaches to learning evaluation of teaching and preferences for contrasting academic environments", Higher Education, 19(2), pp. 169-194. https://doi.org/10.1007/BF00137106

Finna, H., Erdei, J. (2015) "Qualification as a Success Factor in the Labor-Market: The Faculty-Specific Attributes of the Employment of the Budapest University of Technology and Economics Recent Graduates", Acta Polytechnica Hungarica, 12(8), pp. 135-154. https://doi.org/10.12700/APH.12.8.2015.8.8

Ford, J. B., Joseph, M., Joseph, B. (1999) "Importance-performance analysis as a strategic tool for service marketers: the case of service quality perceptions of business students in New Zealand and the USA", Journal of Services Marketing, 13(2), pp. 171-186. https://doi.org/10.1108/08876049910266068 
Geall, V. (2000) "The Expectations and Experience of First-Year Students at City University of Hong Kong", Quality in Higher Education, 6(1), pp. 77-89. https://doi.org/10.1080/13538320050001081

Gil, M. Á., González-Rodríguez, G. (2012) "Fuzzy vs. Likert Scale in Statistics", In: Trillas, E., Bonissone, P. P., Magdalena, L., Kacprzyk, J. (eds.) Combining Experimentation and Theory, Studies in Fuzziness and Soft Computing, , Springer, Berlin, Heidelberg, Germany, pp. 407-420. https://doi.org/10.1007/978-3-642-24666-1_27

Grebennikov, L., Shah, M. (2013) "Monitoring Trends in Student Satisfaction", Tertiary Education and Management, 19(4), pp. 301-322.

https://doi.org/10.1080/13583883.2013.804114

Green, D. (1994) "What Is Quality in Higher Education?", Taylor \& Francis, Bristol, PA, USA.

Gremler, D. D., McCollough, M. A. (2002) "Student Satisfaction Guarantees: An Empirical Examination of Attitudes, Antecedents, and Consequences", Journal of Marketing Education, 24(2), pp. 150-260. [online] Available at: http://ww.gremler.net/personal/research/2002_Satisfaction_ Guarantee_JME.pdf [Accessed: 07 March 2018]

Gruber, T., Fuß, S., Voss, R., Gläser-Zikuda, M. (2010) "Examining student satisfaction with higher education services: Using a new measurement tool", International Journal of Public Sector Management, 23(2), pp. 105-123. https://doi.org/10.1108/09513551011022474

Guolla, M. (1999) "Assessing the Teaching Quality to Student Satisfaction Relationship: Applied Customer Satisfaction Research in the Classroom", Journal of Marketing Theory and Practice, 7(3), pp. 87-97.

https://doi.org/10.1080/10696679.1999.11501843

Hadikoemoro, S. (2001) "A comparison of public and private university students' expectations and perceptions of service quality in Jakarta, Indonesia", D.B.A. Dissertation, Nova Southeastern University, USA.

Harvey, L., Burrows, A., Green, D. (1992) "Total Students Experience: a first report of the QHE National Survey of Staff and Students'Views of the Important Criteria for Assessing the Quality of Higher Education (Birmingham, QHE)", UCE, QHE, Birmingham, England.

Hill, F. M. (1995) "Managing service quality in higher education: the role of the student as primary consumer", Quality Assurance in Education, 3(3), pp. 10-21.

https://doi.org/10.1108/09684889510093497

Hung, Y. H., Huang, M. L., Chen, K. S. (2003) "Service quality evaluation by service quality performance matrix", Total Quality Management \& Business Excellence, 14(1), pp. 79-89. https://doi.org/10.1080/14783360309706

Işık, O., Tengilimoglu, D., Akbolat, M. (2011) "Measuring Health Care Quality with the SERVQUAL Method: A Comparison in Public and Private Hospitals", HealthMED, 5(6), pp. 1921-1930.

Jónás, T., Árva, G., Tóth, Zs. E. (2017) "Application of a Pliant Arithmetic-based Fuzzy Questionnaire to Evaluate Lecturers' Performance", In: 20 $0^{\text {th }}$ QMOD-ICQSS Conference International Conference on Quality and Service Sciences,Elsinore, Denmark, paper B24-4, p. 19.
Khodayari, F., Khodayari, B. (2011) "Service Quality in Higher Education, Case study: Measuring service quality of Islamic Azad University, Firoozkooh branch", Interdisciplinary Journal of Research in Business, 1(9), pp. 38-46. [online] Available at: http:// higheducation.idsc.gov.eg/backend/upload/Quality\%20in\%20 Higher\%20Education.pdf [Accessed: 07 March 2018]

Kincsesné, V. B., Farkas, G., Málovics, É. (2015) "Student evaluations of training and lecture courses: development of the COURSEQUAL method", International Review on Public and Nonprofit Marketing, 12(1), pp. 79-88.

https://doi.org/10.1007/s12208-015-0127-6

Kotler, P., Fox, K. F. A. (1995) "Strategic Marketing for Educational Institutions", 2nd ed., Prentice Hall, New Jersey, USA.

Kuzmanovic, M., Savic, G., Popovic, M., Martic, M. (2013) "A new approach to evaluation of university teaching considering heterogeneity of students' preferences", Higher Education, 66(2), pp. $153-171$.

https://doi.org/10.1007/s10734-012-9596-2

Kwan, K.-P. (1999) "How Fair are Student Ratings in Assessing the Teaching Performance of University Teachers?", Assessment and Evaluation in Higher Education, 24(2), pp. 181-195.

https://doi.org/10.1080/0260293990240207

Lewis, R. C., Booms, B. H. (1983) "The marketing aspects of service quality", In: Berry, L. T., Shostack, G. L., Upah, G. D. (eds.) Emerging Perspective on Service Marketing, American Marketing Association Proceedings Series, Chicago, USA, pp. 99-107.

Lozano, L. M., García-Cueto, E., Muñiz, J. (2008) "Effect of the Number of Response Categories on the Reliability and Validity of Rating Scales", Methodology, 4, pp. 73-79. https://doi.org/10.1027/1614-2241.4.2.73

Lubiano, M. A., de la Rosa de Sáa, S., Montenegro, M., Sinova, B., Gil, M. A. (2016) "Descriptive analysis of responses to items in questionnaires. Why not using a fuzzy rating scale?", Information Science, 360, pp. 131-148.

https://doi.org/10.1016/j.ins.2016.04.029

Lupo, T. (2013) "A fuzzy ServQual based method for reliable measurements of education quality in Italian higher education area", Expert Systems with Applications, 40(17), pp. 7096-7110. https://doi.org/10.1016/j.eswa.2013.06.045

MaCukow, B. (2000) "Education quality in the Warsaw University of Technology - prerequisites and activities already undertaken", European Journal of Engineering Education, 25(1), pp. 9-17. https://doi.org/10.1080/030437900308607

Mahapatra, S. S., Khan, M. S. (2007) "A framework for analysing quality in education settings", European Journal of Engineering Education, 32(2), pp. 205-217. https://doi.org/10.1080/03043790601118606

Mai, L.-W. (2005) "A Comparative Study Between UK and US: The Student Satisfaction in Higher Education and its Influential Factors", Journal of Marketing Management, 21(7-8), pp. 859-878. https://doi.org/10.1362/026725705774538471

Malik, M. E., Naeem, B. (2011) "Banking Clients' Perceived Service Quality and Behavioral Responses" European Journal of Social Sciences, 23(3), pp. 466-473. 
Marsh, H. W., Roche, L. (1993) "The Use of Students' Evaluations and an Individually Structured Intervention to Enhance University Teaching Effectiveness", American Educational Research Journal, 30(1), pp. 217-251. https://doi.org/10.3102/00028312030001217

Martilla, J. A., James, J. C. (1977) "Importance-Performance Analysis", Journal of Marketing, 41(1), pp. 77-79. https://doi.org/10.2307/1250495

Marzo-Navarro, M., Pedraja-Iglesias, M., Rivera-Torres, M. P. (2005) "Measuring customer satisfaction in summer courses", Quality Assurance in Education, 13(1), pp. 53-65. https://doi.org/10.1108/09684880510578650

Mazur, G. H. (1996) "The Application of Quality Function Deployment (QFD) to Design a Course in Total Quality Management (TQM) at the University of Michigan College of Engineering", In: International Conference on Quality: 1996, Yokohama, Japan, pp. 1-7.

McLeay, F., Robson, A., Yusoff, M. (2017) "New applications for importance-performance analysis (IPA) in higher education: Understanding student satisfaction", Journal of Management Development, 36(6), pp. 780-800. https://doi.org/10.1108/JMD-10-2016-0187

Oldfield, B., Baron, S. (2000) "Student perceptions of service quality in a UK university business and management faculty", Quality Assurance in Education, 8(2), pp. 85-95. https://doi.org/10.1108/09684880010325600

O'Neill, M., Palmer, A. (2001) "Survey timing and consumer perceptions of service quality: an overview of empirical evidence", Managing Service Quality: An International Journal, 11(3), pp. 182-190. https://doi.org/10.1108/09604520110391351

O'Neill, M. A., Palmer, A. (2004) "Importance-performance analysis: a useful tool for directing continuous quality improvement in higher education", Quality Assurance in Education, 12(1), pp. 39-52. https://doi.org/10.1108/09684880410517423

Ong, W. M., Nankervis, A. (2012) "Service Quality in Higher Education: Students' Perceptions in Australia and Malaysia", Review of Integrative Business and Economics Research, 1(1), pp. 275-291.

Owlia, M. S., Aspinwall, E. M. (1996) "A framework for the dimensions of quality in higher education", Quality Assurance in Education, 4(2), pp. 12-20. https://doi.org/10.1108/09684889610116012

Palacio, A. B., Meneses, G. D., Pérez, P. J. P. (2002) "The configuration of the university image and its relationship with the satisfaction of students", Journal of Educational Administration, 40(5), pp. 486-505. https://doi.org/10.1108/09578230210440311

Parasuraman, A., Zeithaml, V. A., Berry, L. L. (1985) "A Conceptual Model of Service Quality and Its Implications for Future Research", Journal of Marketing, 49(4), pp. 41-50. https://doi.org/10.2307/1251430

Parasuraman, A., Zeithaml, V. A., Berry, L.L. (1988) "SERVQUAL: A Multi-Item Scale for Measuring Consumer Perceptions of Service Quality", Journal of Retailing, 64(1), pp. 12-40.

Pariseau, S. E., McDaniel, J. R. (1997) "Assessing service quality in schools of business", International Journal of Quality and Reliability Management, 14(3), pp. 204-218. https://doi.org/10.1108/02656719710165455
Paswan A. K., Ganesh G. (2009) "Higher Education Institutions: Satisfaction and Loyalty among International Students", Journal of Marketing for Higher Education, 19(1), pp. 65-84. https://doi.org/10.1080/08841240902904869

Perger, M., Takács, I. (2016) "Factors Contributing to Students' Academic Success Based on the Students' Opinion at BME Faculty of Economic and Social Sciences", Periodica Polytechnica Social and Management Sciences, 24(2), pp. 119-135. https://doi.org/10.3311/PPso.8843

Peters, M. (1992) "Performance indicators in New Zealand higher education: accountability or control?", Journal of Education Policy, 7(3), pp. 267-283. https://doi.org/10.1080/0268093910070302

Prasad, R. K., Jha, M. K. (2013) "Quality Measures in Higher Education: A Review and Conceptual Model", Journal of Research in Business and Management, 1(3), pp. 23-40. [online] Available at: http://www.questjournals.org/jrbm/papers/vol1-issue3/C132340. pdf [Accessed: 07 March 2018]

Quester, P. G., Romaniuk, S., Wilkinson, J. W. (1995) "A Test of Four Service Quality Measurement Scales: The Case of the Australian Advertising Industry", In: Grant, K., Walker, I. (eds.) Proceedings of the 1995 World Marketing Congress, Developments in Marketing Science: Proccedings of the Academy of Marketing Science, Istanbul Turkey, pp. 384-391. https://doi.org/10.1007/978-3-319-17311-5_54

Quirós, P., Alonso, J. M., Pancho, D. P. (2016) "Descriptive and Comparative Analysis of Human Perceptions expressed through Fuzzy Rating Scale-based Questionnaires", International Journal of Computational Intelligence Systems, 9(3), pp. 450-467. https://doi.org/10.1080/18756891.2016.1175811

Qureshi, M. I., Khan, K., Bhatti, M. N., Khan, A., Zaman, K. (2012) "Quality Function Deployment in Higher Education Institutes of Pakistan", Middle-East Journal of Scientific Research, 12(8), pp. 1111-1118. https://doi.org/10.5829/idosi.mejsr.2012.12.8.1639

Ramaiyah, A., Zain, A. N. M., Ahmad, H. B. (2007) "Exploring the Dimensions of Service Quality in Higher Education Research". [online] Available at: http://eprints.um.edu.my/16/1/arivalan.pdf [Accessed: 07 March 2018]

Ramsden, P. (1991) "A performance indicator of teaching quality in higher education: The Course Experience Questionnaire", Studies in Higher Education, 16(2), pp. 129-150. https://doi.org/10.1080/03075079112331382944

Reavill, L. R. P. (1998) "Quality assessment, total quality management and the stakeholders in the UK higher education system", Managing Service Quality: An International Journal, 8(1), pp. 55-63. https://doi.org/10.1108/09604529810199395

Richardson, J. T. E. (2005) "Students' Approaches to Learning and Teachers' Approaches to Teaching in Higher Education", Educational Psychology: An International Journal of Experimental Educational Psychology, 25(6), pp. 673-680. https://doi.org/10.1080/01443410500344720

Rigotti, S., Pitt, L. (1992) "SERVQUAL as a Measuring Instrument for Service Provider Gaps in Business Schools", Management Research News, 15(3), pp. 9-17. https://doi.org/10.1108/eb028197 
Roberts, D., Higgins, T. (1992) "Higher Education: the student experience. The Findings of a Research Programme into Student DecisionMaking and Consumer Satisfaction", Heist Research, Leeds.

Rodríguez-González, F. G., Segarra, P. (2016) "Measuring academic service performance for competitive advantage in tertiary education institutions: the development of the TEdPERF scale", International Review on Public and Nonprofit Marketing, 13(2), pp. 171-183. https://doi.org/10.1007/s12208-016-0159-6

Rowley, J. (1997) "Beyond service quality dimensions in higher education and towards a service contract", Quality Assurance in Education, 5(1), pp. 7-14. https://doi.org/10.1108/09684889710156530

Rowley, J. (2003) "Designing student feedback questionnaires", Quality Assurance in Education, 11(3), pp. 142-149. https://doi.org/10.1108/09684880310488454

Sander, P., Stevenson, K., King, M., Coates, D. (2000) "University Students' Expectations of Teaching", Studies in Higher Education, 25(3), pp. 309-323. https://doi.org/10.1080/03075070050193433

Senthilkumar, N., Arulraj, A. (2011) "SQM-HEI - determination of service quality measurement of higher education in India", Journal of Modelling in Management, 6(1), pp. 60-78. https://doi.org/10.1108/17465661111112502

Sirvanci, M. (1996) "Are Students the True Customers of Higher Education?", Quality Progress, 29(10), pp. 99-102.

Soutar, G., McNeil, M. (1996) "Measuring service quality in a tertiary institution", Journal of Educational Administration, 34(1), pp. $72-82$.

https://doi.org/10.1108/09578239610107174

Sowa, J. F. (2013) "What Is the Source of Fuzziness?", In: Seising, R., Trillas, E., Moraga, C., Termini, S. (eds.) On Fuzziness, Studies in Fuzziness and Soft Computing, Springer, Berlin, Heidelberg, Germany, pp. 645-652.

https://doi.org/10.1007/978-3-642-35644-5_31

Tam, M. (2001) "Measuring Quality and Performance in Higher Education", Quality in Higher Education, 7(1), pp. 47-54. https://doi.org/10.1080/13538320120045076

Teas, R. K. (1993) "Expectations, Performance Evaluation, and Consumers' Perceptions of Quality", Journal of Marketing, 57(4), pp. 18-34. https://doi.org/10.2307/1252216

Teeroovengadum, V., Kamalanabhan, T. J., Seebaluck, A. K. (2016) "Measuring service quality in higher education: Development of a hierarchical model (HESQUAL)", Quality Assurance in Education, 24(2), pp. 244-258.

https://doi.org/10.1108/QAE-06-2014-0028

Tóth, Zs. E., Jónás, T., Bérces, R., Bedzsula, B. (2013) "Course evaluation by importance-performance analysis and improving actions at the Budapest University of Technology and Economics", International Journal of Quality and Service Sciences, 5(1), pp. 66-85.

Tóth, Zs. E., Jónás, T. (2014) "Enhancing Student Satisfaction Based on Course Evaluations at Budapest University of Technology and Economics", Acta Polytechnica Hungarica, 11(6), pp. 95-112. https://doi.org/10.12700/APH.11.06.2014.06.6
Tóth, Zs. E., Árva, G., Surman, V. (2017) "Enhancing the Reliability of Measurements and Evaluations Based on Service Quality Models", In: Bekirogullari, Z., Minas, M. Y., Thambusamy, R. X. (eds.) The European Proceedings of Social \& Behavioural Sciences EpSBS, 31, pp. 642-653.

http://doi.org/10.15405/epsbs.2017.10.61

Trivellas, P., Dargenidou, D. (2009) "Leadership and service quality in higher education: The case of the Technological Educational Institute of Larissa", International Journal of Quality and Service Sciences, 1(3), 294-310. https://doi.org/10.1108/17566690911004221

Venkatraman, S. (2007) "A framework for implementing TQM in higher education programs", Quality Assurance in Education, 15(1), pp. $92-112$. https://doi.org/10.1108/09684880710723052

Voss, R., Gruber, T., Szmigin, I. (2007) "Service quality in higher education: The role of student expectations", Journal of Business Research, 60(9), pp. 949-959. https://doi.org/10.1016/j.jbusres.2007.01.020

Watson, S., Saldana, A., Harvey, L. (2002) "The 2002 Report on the Student Experience at UCE", Centre for Research into Quality, UCE, Birmingham, UK.

Wiers-Jenssen, J., Stensaker, B., GrØgaard, J. B. (2002) "Student Satisfaction: Towards an empirical deconstruction of the concept", Quality in Higher Education, 8(2), pp. 183-195. https://doi.org/10.1080/1353832022000004377

Williams, J. (2002) "The Student Satisfaction Approach: a British model of effective use of student feedback in quality assurance and enhancement", presented at the $14^{\text {th }}$ International Conference on Assessing Higher Education, Vienna, Austria, Jul. 24-27, 2002.

Wong, K.-L., Ong, S.-F., Kuek, T.-Y. (2012) "Constructing a Survey Questionnaire to Collect Data on Service Quality of Business Academics", European Journal of Social Sciences, 29(2), pp. 209-221.

Wright, C., O'Neill, M. (2002) "Service Quality Evaluation in the Higher Education Sector: An Empirical Investigation of Students' Perceptions", Higher Education Research and Development, 21(1), pp. 23-39.

https://doi.org/10.1080/07294360220124639

Yeo, R. K. (2008) "Brewing service quality in higher education: Characteristics of ingredients that make up the recipe", Quality Assurance in Education, 16(3), pp. 266-286. https://doi.org/10.1108/09684880810886277

Yousapronpaiboon, K. (2014) "SERVQUAL: Measuring Higher Education Service Quality in Thailand", Procedia - Social and Behavioral Sciences, 116, pp. 1088-1095. https://doi.org/10.1016/j.sbspro.2014.01.350

Zeithaml, V. A., Bitner, M. J. (2002) "Services Marketing", 3rd ed., McGraw-Hill Education, New York, USA. 